\section{A study of the properties, reactivity and anticancer activity of novel Nmethylated-3-thiazolyl or 3- thienyl carbazoles and their Pd(II) and Pt(II) complexes}

a Grup de Materials Orgànics, Institut de Nanociència i Nanotecnologia (IN2UB), Secció de Química Orgànica, Departament de Química Inorgànica i Orgànica, Facultat de Química, Martí i Franquès 1-11, E-08028 Barcelona, Spain

b Secció de Química Inorgànica, Departament de Química Inorgànica i Orgànica, Facultat de Química, Martí i Franquès 1-11, E-08028 Barcelona, Spain

c Unitat de Difracció de Raigs-X, Centres Científics i Tecnològics (CCiT), Universitat de Barcelona, Solé i Sabaris 1-3, E-08028 Barcelona, Spain

d Biomed Division, Health \& Biomedicine Unit, LEITAT Technological Center, Parc Científic de Barcelona, Edifici Hèlix, Baldiri i Reixach 13-21, E-08028 Barcelona, Spain

e Secció de Bioquímica i Biología Molecular, Departament de Bioquímica i Fisiologia, Facultat de Farmàcia i Ciències de l'Alimentació, Universitat de Barcelona, Av. Joan XXIII 27-31, E-08028 Barcelona, Spain

f Institut de Biomedicina de la Universitat de Barcelona - Institut Recerca Sant Joan de Deu, Barcelona, Spain

conchi.lopez@qi.ub.es (C. López). 


\section{ABSTRACT:}

54 The synthesis and characterization of two hybrid N-methylated carbazole derivatives containing a

55 thiazolyl or a thienyl ring is reported. The thiazolyl derivative has been also characterised by X-ray

56 diffraction analysis. The study of its reactivity in front of [MCl2(dmso)2] ( $\mathrm{M}=\mathrm{Pd}$ or Pt) or Na2[PdCl4]

57 in methanol has allowed us to isolate and characterize its complexes. However, for the thienyl analogue,

58 the formation of any $\mathrm{Pd}(\mathrm{II})$ or $\mathrm{Pt}(\mathrm{II})$ complex was not detected, indicating that it is less prone to bind to

59 the M(II) ions than its thiazolyl analogue. Density Functional Theory (DFT) and Time-Dependent

60 Density Functional Theory (TD-DFT) calculations have also been carried out in order to rationalize the

61 influence of the nature of the thiazolyl or thienyl group on the electronic delocalization. Molecular

62 mechanics calculations show that the free rotation of the thiazolyl in relation to the carbazole requires a

63 greater energy income than for its thienyl analogue. Studies of the cytotoxic activity of the new

64 compounds on colon (HCT116) and breast (MDA-MB231 and MCF7) cancer cell lines show that the

65 thiazolyl carbazole ligand and its Pt(II) complex are the most active agents of the series and in the

66 MCF7 line their potency is higher than that of cisplatin. In the non-tumoral human skin fibroblast BJ

67 cell line, all the compounds were less toxic than cisplatin. Their potential ability to modify the

68 electrophoretic mobility of pBluescript SK+ plasmid DNA and to act as inhibitors of Topoisomerases I

69 and II $\alpha$ or cathepsin B has also been investigated. 
73 Cancer is among the leading causes of morbidity and death that unfortunately affects millions of persons worldwide (i.e. more than one million each year in USA [1]). The American Cancer Society estimates an incidence of ca. 1.7 million new cases for 2017 and $>0.6$ million deaths [2] mainly produced by colorectal, breast, lung and ovarian cancers [2-4]). Every cancer type needs a specific treatment protocol that usually involves chemotherapy (CT) [5], radiotherapy and/or surgery. The development of new antitumor drugs with improved activities and lower side effects than those used nowadays in CT is still one of the main challenges of current research in medicinal chemistry. Among the variety of strategies used nowadays in drug discovery [6-11], those with greater expectations are based on: a) natural products and/or b) new synthetic products with several bioactive arrays (i.e. by incorporation of an additional bioactive unit in the backbones of commercially available pharmaceuticals or known drugs and commonly known as "molecular hybridization approach") [6-11].

On the other hand, it is well-known that heterocycles and their derivatives are one of the most important types of organic compounds due to their outstanding physical and photo-optical properties, their rich reactivity, their utility as ligands in Coordination and Organometallic Chemistry and their multiple applications in a variety of fields, including medicinal chemistry [12-21]. Heterocyclic cores are present in huge range of natural and marketed antimicrobial, anti-inflammatory, antiviral, anticancer, antihypertensive, antimalarial, anti-HIV, antidepressant, antihelmintic drugs, among others. Their relevance in new drugs design and development is undeniable [12-14]. For instance, among all the anticancer drugs approved by FDA during the late five years ca. $75 \%$ have heterocyclic arrays with $\mathrm{N}$ and/or S atoms or polycyclic aromatic compounds with heterocyclic fragments [15-22]. Carbazole (Fig. 1), thiazole and thiophene are probably three of the most important scaffolds in drug design and discovery [23-33]. These units are present in diverse bioactive synthetic -and even in naturally occurring products. For instance, Ellipticine and Glybomine-C (Fig. 1) isolated from plants, are potent cytotoxic agents in several cancer cell lines [34,35] and the discovery that $\mathrm{N}$-alkylation of Ellipticine enhanced inhibition growth activity has stimulated the interest on $\mathrm{N}$-substituted carbazoles [23-26,34,35]. The number of potent cytotoxic (substituted and/or anellated) carbazoles reported in the last 2 years has grown exponentially and according to a recent review published by Caruso et al. [26]: "Carbazoles are promising scenarios for breast cancer treatments". In addition to carbazoles, and in a lesser extent, thiazole and thiophene derivatives are gaining increasing interest as "central cores" or as "pendant" groups in drug engineering and specially as promising platforms or "templates" to build up new and more efficient antitumor agents that could overcome or at least reduce the main problems (i.e. drug resistance, toxicity, or other undesirable side effects) associated to drugs used currently. cis-[PtCl2(NH3)2] (cisplatin) and doxorubicin [4,36-40] are two CT agents used in cancer treatments that may generate severe-side effects (i.e. nephrotoxicity, neurotoxicity, the increase of blood pressure, severe nausea, vomiting, or diarrhoea produced by 
cisplatin or severe heart problems (cardiomyopathy) associated to doxorubicin [36-40]). Since the discovery of cisplatin, the development of metal coordination complexes as anticancer agents has attracted a great deal of interest to obtain more effective and less toxic drugs [41]. For instance, transplatinum(II) based complexes or those based on less toxic metals (ruthenium, gold or copper) are shown to be promising candidates in safer cancer therapy. Despite of the interest in electronics and materials science arisen by hybrid carbazole/thienyl derivatives [42-52] and the potential synergic effect of the presence of two bioactive arrays [i.e. the N-substituted carbazole and a thiazole (or a thienyl) unit] in the same molecule that could be relevant in drug design $[53,54]$ and in photodynamic therapy (PTD) [55], studies on their biological activities are scarce.

117 Moreover, it is well-known that heterocycles are valuable ligands in Coordination and Organometallic

118 Chemistry [15-17] and their binding to a transition metal ion $(\mathrm{Mm}+)$ commonly affects their properties

119 and their biological and/or catalytic activities. For instance, $\mathrm{Pd}(\mathrm{II})$ and $\mathrm{Pt}(\mathrm{II})$ complexes with

120 heterocyclic ligands (i.e. pyrazoles, indoles) showing greater cytotoxic activity than the free ligands have been reported [56-60]. However, parallel studies on hybrid carbazole/thiazole or thiophene derivatives have not been investigated yet. Therefore, there is a lack of information on their coordination ability and the effect produced by the binding of these ions on their properties and especially on their cytotoxic activity.

125 In this paper, we present two new carbazole derivatives: 9-methyl-3- (2-thiazolyl)-9H-carbazole (1a)

126 and 9-methyl-3-(2-thienyl)-9H-carbazole (1b) shown in Scheme 1, a study of their reactivity in front of

$127 \mathrm{Pd}$ (II) and $\mathrm{Pt}(\mathrm{II})$, their spectroscopic properties and the anticancer activity of the free ligands and the new Pd(II) and Pt(II) complexes, trans- [PdCl2(1a)2] (2a) and trans-[PtCl2(1a)dmso] (3a). 


\section{EXPERIMENTAL}

\subsection{Chemistry}

133

2.1.1. Materials and methods

[MCl2(dmso)2] \{trans- for $\mathrm{M}=\mathrm{Pd}$ or cis- for $\mathrm{M}=\mathrm{Pt}\}$ and 3-iodo-9H-carbazole were prepared as described previously [61-63], and the remaining reagents were obtained from commercial sources and used as received. The success of the synthesis of the $\mathrm{Pt}(\mathrm{II})$ compound $3 \mathrm{a}$ is strongly dependent on the quality of the methanol; the presence of water produces the formation of metallic platinum, other undesirable minor by-products and a significant decrease in the yield. Thus, the use of high quality $\mathrm{MeOH}$ (HPLC grade) is required. The remaining solvents used were dried and distilled before use [64] During the preparation of the complexes ( $2 a$ and $3 a$ ), the reaction flask was protected from the light with aluminium foil. Elemental analysis were carried out at the Centres Científics i Tecnològics (CCiT, Univ. Barcelona) with an Eager 1108 microanalyzer. Mass spectra (ESI+) were performed at the Servei d'Espectrometria de Masses (Univ. de Barcelona) using a LC/MSD-TOF Agilent Technologies instrument. UV-vis. spectra of $\mathrm{CH} 2 \mathrm{Cl} 2$ solutions of the free ligands (1a and $1 \mathrm{~b}$ ) and complexes $2 \mathrm{a}$ and 3a were recorded at $298 \mathrm{~K}$ with a Varian Cary UV-Vis-NIR 500E spectrometer and their emission spectra were obtained on a PTI fluorimeter equipped with a 220B lamp power supply, a 815 photomultiplier detection system and Felix 32 software at $298 \mathrm{~K}$ in $\mathrm{CH} 2 \mathrm{Cl} 2$ solutions. 1,4-Bis(5-phenyl2-oxazolyl) benzene (POPOP) dissolved in cyclohexane was used as a standard for the fluorescence quantum yield determination $(\lambda \mathrm{exc}=300 \mathrm{~nm}, \Phi P O P O P=0.93) .1 \mathrm{H}$ and $13 \mathrm{C}\{1 \mathrm{H}\}$-NMR spectra were recorded at $298 \mathrm{~K}$ in acetone-d6 for the precursor (3-iodo-9-methyl-9H-carbazole) or in $\mathrm{CDCl} 3$ (in the remaining cases) with a Varian Mercury $400 \mathrm{MHz}$ or a Bruker $400 \mathrm{MHz}$ Avance III [for $1 \mathrm{H}$ and $13 \mathrm{C}\{1 \mathrm{H}\}]$ and a Bruker $250 \mathrm{MHz}$ and a Bruker 400 Avance III HD (for 195Pt $\{1 \mathrm{H}\}$ ) spectrometers. Chemical shifts are given in $\delta$ values (ppm) using the solvent peaks as internal references (1H and 13C) and $\mathrm{H} 2 \mathrm{PtCl} 6$ in D2O $(195 \mathrm{Pt}\{1 \mathrm{H}\})$ and coupling constants $(\mathrm{J})$ are given in $\mathrm{Hz}$. Abbreviations used for the multiplicities are as follows: $s$ (singlet), $d$ (doublet), dd (doublet of doublets), $t$ (triplet), $q$ (quadruplet) and $\mathrm{m}$ (multiplet). The atom numbering system used in the assignment of $1 \mathrm{H}$ and $13 \mathrm{C}\{1 \mathrm{H}\}-\mathrm{NMR}$ data is shown in Fig. 2.

\subsubsection{Synthesis of ligands $1 \mathrm{a}$ and $1 \mathrm{~b}$}

2.1.2.1. Synthesis of the precursor 3-iodo-9-methyl-9H-carbazole. NaH (240 mg, $6.00 \mathrm{mmol}, 60 \%$ dispersion in mineral oil) was added to a solution of 3-iodo-9H-carbazole $(1.60 \mathrm{~g}, 5.46 \mathrm{mmol})$ in anhydrous DMF $(10 \mathrm{~mL})$ under nitrogen atmosphere. The solution was stirred at room temperature for $30 \mathrm{~min}$. Then, iodomethane $(374 \mu \mathrm{L}, 6.00 \mathrm{mmol})$ was added and the mixture was stirred at room 
191

the organic layer was dried over $\mathrm{Na} 2 \mathrm{SO} 4$, filtered off and the solvent was distilled off under reduced pressure. The crude was purified by flash column chromatography using a mixture of hexane and ethyl acetate $(20: 1 \mathrm{v} / \mathrm{v})$ as the eluent to give 3-iodo-9-methyl-9H-carbazole $(1.45 \mathrm{~g}, 86 \%)$. 1H NMR (400 MHz, acetone-d6) $\delta(\mathrm{ppm}): 8.49$ (d, 4JHH= 1.7, 1H, H4), 8.17 (d, 3JH-H=7.6, 1H, H5), 7.74 (dd, 3JH$\mathrm{H}=8.6,4 \mathrm{JH}-\mathrm{H}=1.7,1 \mathrm{H}, \mathrm{H} 2), 7.55$ (d, 3JH-H=8.2, 1H, H8), 7.53-7.48 (m, 1H, H7), 7.42 (d, 3JH-H=8.6, 1H, H1), 7.26-7.22 (m, 1H, H6), 3.91 (s, NMe, 3H). CI-MS (m/z): calc. For C13H11IN (M+H)+ 308.0, found: 308.0 .

2.1.2.2. Synthesis of 9-methyl-3-(2-thiazolyl)-9H-carbazole (1a). A mixture of 3-iodo-9-methyl-9Hcarbazole (1.24 g, $4.04 \mathrm{mmol}), 2$ - (tributylstannyl)thiazole (1.81 g, $4.84 \mathrm{mmol})$ and Pd(PPh3)4 (231 mg, $0.20 \mathrm{mmol})$ in anhydrous DMF $(10 \mathrm{~mL})$ was heated to $100^{\circ} \mathrm{C}$ under a nitrogen atmosphere for $20 \mathrm{~h}$. Then, the reaction mixture was cooled down to room temperature, treated with water and the product was extracted with dichloromethane. The organic layer was dried over Na2SO4, filtered off and the solvent was distilled off under reduced pressure. The crude was purified by flash column chromatography using a mixture of hexane and $\mathrm{CH} 2 \mathrm{Cl} 2(5: 1 \mathrm{v} / \mathrm{v})$ as the eluent to give compound 1a (420 mg, 39\%). 1H NMR (400 MHz, CDCl3) $\delta$ (ppm): 8.73 (d, 4JH-H=1.7, 1H, H4), 8.16 (d, 3JH$\mathrm{H}=8.0,1 \mathrm{H}, \mathrm{H} 5), 8.10(\mathrm{dd}, 3 \mathrm{JHH}=8.6,4 \mathrm{JH}-\mathrm{H}=1.7,1 \mathrm{H}, \mathrm{H} 2), 7.87$ (d, 3JH-H=3.3, 1H, H4'), 7.54-7.50 (m, 1H, H7), 7.44 (d, 3JH-H=8.6, 1H, H1), 7.43 (d, 3JH-H=8.2, 1H, H8), 7.31-7.27 (m, 2H, H6 and H5'), 3.89 (s, 3H, NMe). 13C NMR (100 MHz, CDCl3) $\delta$ (ppm): 170.0 (C2'), 143.4 (C4'), 142.2 (C9a), 141.7 (C8a), 126.5 (C7), 125.1 (C3), 124.9 (C2), 123.3 (C4a), 123.0 (C5a), 120.8 (C5), 119.7 (C6), 119.0 (C4), 117.8 (C5'), 108.9 (2C, C1 and C8), 29.4 (NCH3). HRMS (ESI-MS) (m/z): calc. for C16H13N2S (M+H)+: 265.0794, found: 265.0796. Elemental Anal. (\%). Calc. for C16H12N2S $(\mathrm{MW}=264.34)$. C, 72.70; H, 4.58; N, 10.60 and $\mathrm{S}, 12.13$; found: $\mathrm{C}, 72.65 ; \mathrm{H}, 4.65 ; \mathrm{N}, 10.53$; and $\mathrm{S}$, 11.86 .

2.1.2.3. Synthesis of 9-methyl-3-(2-thienyl)-9H-carbazole (1b). A mixture of 3-iodo-9-methyl-9Hcarbazole (771 mg, $2.51 \mathrm{mmol})$, 2-(tributylstannyl)thiophene (1.12 g, $3.00 \mathrm{mmol})$ and Pd(PPh3)4 (139 $\mathrm{mg}, 0.12 \mathrm{mmol})$ in anhydrous DMF $(10 \mathrm{~mL})$ was heated to $100^{\circ} \mathrm{C}$ under a nitrogen atmosphere for $24 \mathrm{~h}$. Then, the reaction mixture was cooled down to room temperature, treated with water and the product was extracted with dichloromethane. The organic layer was dried over Na2SO4, filtered off and the solvent was distilled off under reduced pressure. The crude was purified by flash column chromatography using a mixture of hexane and dichloromethane $(9: 1 \mathrm{v} / \mathrm{v})$ as the eluent to give compound $1 \mathrm{~b}(343 \mathrm{mg}, 52 \%)$. 1H NMR (400 MHz, CDCl3) $\delta(\mathrm{ppm}): 8.32$ (d, 4JH-H=1.8, 1H, H4), 8.14 (d, 3JH-H=7.7, 1H, H5), 7.75 (dd, 3JH-H=8.5, 4JH-H=1.8, 1H, H2), 7.52-7.48 (m, 1H, H7), 7.41 (d, $3 \mathrm{JH}-\mathrm{H}=8.1,1 \mathrm{H}, \mathrm{H} 8), 7.40(\mathrm{~d}, 3 \mathrm{JH}-\mathrm{H}=8.5 \mathrm{~Hz}, 1 \mathrm{H}, \mathrm{H1}), 7.35$ (dd, 3JHH= 3.6, 4JH-H=1.0, 1H, H3'), 7.28-7.24 (m, 2H, H5' and H6), 7.11 (dd, 3JH-H=5.1, 3JH-H=3.6, 1H, H4'), 3.87 (s, 3H, NMe). 13C NMR (100 MHz, CDC13) $\delta$ (ppm): 146.0 (C2'), 141.6 (C8a), 140.7 (C9a), 128.1 (C4'), 126.2 (C7), 
125.9 (C3), 124.5 (C2), 123.8 (C5'), 123.3 (C4a), 122.9 (C5a), 122.2 (C3'), 120.6 (C5), 119.3 (C6), 118.0 (C4), 108.9 (C1 or C8), 108.8 (C1 or C8), 29.4 (NMe). HRMS (ESI-MS) (m/z): calc. for C17H14NS (M+H)+ 264.0841, found: 264.0843; elemental Anal (\%). Calc. for C17H13NS (MW=263.34). C, 77.53; H, 4.98; N, 5.32 and S, 12.70; found: $\mathrm{C}, 77.45 ; \mathrm{H}, 5.04 ; \mathrm{N}, 5.25 ;$ and $\mathrm{S}, 12.61$.

\subsubsection{Preparation of the complexes $2 \mathrm{a}$ and $3 \mathrm{a}$}

2.1.3.1. Synthesis of compound 2a. This compound was obtained using two alternative procedures that differ in the nature of the starting $\mathrm{Pd}(\mathrm{II})$ complex used as reagent: trans-[PdCl2(dmso)2] or Na2[PdCl4] \{methods a) and b), respectively\}. Method b) allows the isolation of compound 2a with a higher yield (and at lower temperatures) than using method a). Method a) trans-[PdCl2(dmso)2] (63 mg, $0.19 \mathrm{mmol}$ ) was treated with $30 \mathrm{~mL}$ of methanol, refluxed until complete dissolution and filtered out. Then, $50 \mathrm{mg}$ $(0.19 \mathrm{mmol})$ of carbazole $1 \mathrm{a}$, were added to the hot filtrate and the mixture was refluxed for $1 \mathrm{~h}$. After this period, the resulting solution was allowed to cool down to room temperature and the solid formed was collected by filtration, air-dried and later on dried in vacuum for 2 days. (Yield: $38 \mathrm{mg}, 28 \%$ ). Method b) A solution containing Na2[PdCl4] (28 mg, $0.095 \mathrm{mmol})$ and $20 \mathrm{~mL}$ of methanol was added to another one formed by ligand $1 \mathrm{a}(50 \mathrm{mg}, 0.19 \mathrm{mmol})$ and $5 \mathrm{~mL}$ of methanol. The resulting mixture was stirred for $24 \mathrm{~h}$ at $298 \mathrm{~K}$. After this period, the solid formed was collected by filtration and dried as in Method a) (Yield: $55 \mathrm{mg}, 82 \%$ ). 1H NMR (400 MHz, CDCl3) $\delta$ (ppm): 9.22 (d, 4JH-H=1.8, 2H, 2H4), 8.47 (dd, 3JH-H=8.5, 4JH-H=1.8, 2H, 2H2), 8.19 (d, 3JH-H=7.7, 2H, 2H5), 8.08 (d, 3JH-H=3.7, 2H, 2H4'), 7.58-7.44 (m, 8H, 2H1, 2H7, 2H8 and 2H5'), 7.32 (t, 3JH-H=7.7, 2H, 2H6), 3.93 (s, 6H, 2NMe). Elemental Anal. (\%). Calc. for C32H24Cl2N4PdS2 (MW=706.01). C, 54.44; H, 3.43; N, 7.94 and S, 9.08; found: C, 54.50; H, 3.50; N, 8.03 and S, 8.85.

2.1.3.2. Synthesis of compound 3a. cis-[PtCl2(dmso)2] ( $80 \mathrm{mg}, 0.19 \mathrm{mmol})$ was suspended in $30 \mathrm{~mL}$ of methanol, until complete dissolution. Then, the hot solution was filtered out and the filtrate was poured into a methanol solution $(5 \mathrm{~mL})$ of ligand $1 \mathrm{a}(50 \mathrm{mg}, 0.19 \mathrm{mmol})$. The reaction flask was protected from light with aluminium foil and the mixture was refluxed for $1 \mathrm{~h}$ and filtered. Then, the filtrate was afterwards concentrated to dryness on a rotary evaporator and the residue was dried in vacuum for $24 \mathrm{~h}$. After this period, the solid was dissolved in the minimum amount of $\mathrm{CH} 2 \mathrm{Cl} 2$ (ca. $15 \mathrm{~mL}$ ) and passed through a short $\mathrm{SiO} 2$ column $(5.0 \mathrm{~cm} \times 1.5 \mathrm{~cm})$. Elution with $\mathrm{CH} 2 \mathrm{Cl} 2$ released a pale yellowish band that was collected and concentrated to dryness on a rotary evaporator giving 3a (yield: $69 \mathrm{mg}, 60 \%$ ). $195 \mathrm{Pt}\{1 \mathrm{H}\}$-NMR data (54 MHz, CDCl3) $\delta$ (ppm): -2983 (s). 1H NMR-data (400 MHz, CDCl3) $\delta$ (ppm): 9.22 (d, 4JH-H=1.8, 1H, H4), 8.47 (dd, 3JH-H=8.5, 4JH-H=1.8, 1H, H2), 8.20 (d, 3JH-H=7.7, 1H, H5), 8.08 (d, 3JH-H=3.7, 1H, H4'), 7.58-7.54 (m, 2H, H1 and H7), 7.47 (d, 3JH-H=8.2, 1H, H8), 7.46 (d, 3JH-H=3.7, 1H, H5'), 7.34-7.30 (m, 1H, H6), 3.94 (s, 3H, NMe), 3.37 (s, 6H, dmso). ESI-MS $(\mathrm{m} / \mathrm{z})$ : calc. for $\mathrm{C} 18 \mathrm{H} 19 \mathrm{Cl} 2 \mathrm{~N} 2 \mathrm{OPtS} 2(\mathrm{M}+\mathrm{H})+608.0$, found: 608.0. Elemental Anal. (\%). Calc. for: 
C18H18Cl2N2OPtS2 (MW=608.46): C, 35.53; H, 2.98; N, 4.60 and S, 10.54; found C, 35.59; H, 3.05;

$\mathrm{N}, 4.63$ and $\mathrm{S}, 10.60$.

2.1.3.3. Synthesis of the two isomers of $[\mathrm{PtCl} 2(1 \mathrm{a})(\mathrm{dmso})]$ \{trans-(3a) and cis-(4a)\}. NaAcO $(16 \mathrm{mg}$, $0.19 \mathrm{mmol}$ ) was dissolved in $5 \mathrm{~mL}$ of methanol at $298 \mathrm{~K}$ and then added dropwise to a mixture formed by carbazole 1a (50 mg, $0.19 \mathrm{mmol})$, cis-[PtCl2(dmso)2] ( $80 \mathrm{mg}, 0.19 \mathrm{mmol})$ and $25 \mathrm{~mL}$ of toluene. The flask was protected from the light with aluminium foil and refluxed for 3 days. After this period the deep brown solution was filtered through a Celite pad, and the filtrate was concentrated on a rotary evaporator. The dark residue was dried in vacuum for $24 \mathrm{~h}$, dissolved in $\mathrm{CH} 2 \mathrm{Cl} 2$ (ca. $30 \mathrm{~mL}$ ) and finally passed through a short $(5.0 \mathrm{~cm} \times 1.5 \mathrm{~cm}) \mathrm{SiO} 2$ column. Elution with $\mathrm{CH} 2 \mathrm{Cl} 2$ released a wide pale yellow band that was collected in portions (ca. $25 \mathrm{~mL} / \mathrm{each}$ ). The first collected fractions ca. $120 \mathrm{~mL}$ gave after concentration $11 \mathrm{mg}$ of $3 \mathrm{a}$; while the remaining subsequent fractions eluted (ca. $200 \mathrm{~mL}$ ) gave, after concentration a solid (26 mg) containing isomers $3 \mathrm{a}$ and $4 \mathrm{a}$ (in a ca. equimolar ratio. \%). $195 \mathrm{Pt}\{1 \mathrm{H}\}$ NMR data (54 MHz, CDCl3, see also Fig. S1, A) $\delta$ (ppm): -2980 (s) (trans-isomer, 3a) and-2932 (s) (cis-isomer, 4a); $1 \mathrm{H}$ NMR data (400 MHz, CDCl3) $\delta$ (ppm): (see also Fig. S1, B): 9.22 (d, 4JH-H=1.8, 1H, $\mathrm{H} 4$ of 3a), 8.47 (dd, 3JH-H=8.5, 4JH-H=1.8, 1H, H2 of 3a), 8.20 (d, 3JH-H=7.7, 1H, H5 of 3a), $8.08(\mathrm{~d}, 3 \mathrm{JH}-\mathrm{H}=3.7,1 \mathrm{H}, \mathrm{H} 4$ ' of 3a), 7.58-7.54 (m, 2H, H1 and $\mathrm{H} 7$ of 3a), 7.47 (d, 3JH-H=8.2, 1H, H8 of 3a), 7.46 (d, 3JH-H=3.7, 1H, H5'), 7.34-7.30 (m, 1H, H6 of 3a), 3.98 (s, 3H, NMe of 4a); 3.94 (s, $3 \mathrm{H}, \mathrm{NMe}$ of 3a), 3.37 (s, 6H, Me(dmso) of 3a); 3.25 [s, 3H, Me(dmso) of 4a]; and 2.29 [s, 3H, $\mathrm{Me}(\mathrm{dmso})$ of 4a]. ESI-MS (m/z): calc. for C18H19C12N2OPtS2 $(\mathrm{M}+\mathrm{H})+=608.0$; found: 608.0 . Elemental Anal. (\%). Calc. for: C18H18C12N2OPtS2 (MW=608.46): C, 35.53; H, 2.98; N, 4.60 and S, 10.54; found $\mathrm{C}, 35.59 ; \mathrm{H}, 3.15 ; \mathrm{N}, 4.54$ and $\mathrm{S}, 10.37$.

\subsection{Crystallography}

A colourless prism-like specimen of C16H12N2S (1a) (sizes in Table 1) was used for the X-ray crystallographic analysis. The X-ray intensity data were measured on a D8 Venture system equipped with a multilayer monochromator and a Mo microfocus $(\lambda=0.71073 \AA)$. The frames were integrated with the Bruker SAINT software package using a narrow-frame algorithm. The integration of the data using an orthorhombic unit cell yielded a total of 7259 reflections to a maximum $\theta$ angle of $27.50^{\circ}(0.77 \AA$ resolution), of which 2855 were independent (average redundancy 2.543 , completeness $=99.9 \%$, Rint $=3.42 \%$, Rsig $=4.25 \%)$ and $2482(86.94 \%)$ were greater than $2 \sigma(\mathrm{F} 2)$. The final cell constants given in Table 1 are based upon the refinement of the XYZ-centroids of reflections above $20 \sigma(\mathrm{I})$. The calculated minimum and maximum transmission coefficients (based on crystal size) are 0.6711 and 0.7456. The structure was solved using the Bruker SHELXTL Software Package, and refined using SHELXL [65], using the space group P212121, with $Z=4$ for the formula unit, $\mathrm{C} 16 \mathrm{H} 12 \mathrm{~N} 2 \mathrm{~S}$. The final anisotropic full-matrix least-squares refinement on $\mathrm{F} 2$ with 173 variables converged at $\mathrm{R} 1=3.58 \%$, for the observed data and $\mathrm{wR} 2=8.01 \%$ for all data. The goodness-of-fit was 1.074 . The largest peak in the 
277 final difference electron density synthesis was $0.241 \mathrm{e}-/ \AA 3$ and the largest hole was $-0.234 \mathrm{e}-/ \AA 3$ with

278 an RMS deviation of $0.053 \mathrm{e}-/ \AA 3$. Further details concerning the resolution and refinement of the crystal

279 structure are presented in Table 1. CCDC-1560144 contains the crystallographic data of this paper.

280 These data can be obtained from the Cambridge Crystallographic Data Centre via:

281 www.ccdc.cam.ac.uk/data. request.cif.

282

\subsection{Computational details}

284 The conformational map has been searched at the molecular mechanics level using the augmented 285 MMFF94 method [66] as implemented in Spartan [67]. The dihedral angle S1-C2-C3-C4 ( $\varphi$ ) has been 286 sampled every $5^{\circ}$ and the remaining geometric parameters have been fully optimized. DFT [68]

287 calculations have been performed using the B3LYP functional [69,70] implemented in the Gaussian 03 288 software [71] and the 6-31G* basis set [72,73], including polarization functions for the non-hydrogen 289 atoms.

\subsection{Biological studies}

2.4.1. Cell culture

293 Colon adenocarcinoma (HCT116) cells (from the American Type Culture Collection) and breast cancer 294 (MDA-MB231 and MCF7) cells (from European Collection of Cell Cultures, ECACC) were used for all 295 the experiments. Cells were grown as a monolayer culture in DMEM-high glucose (Sigma, D5796) in 296 the presence of $10 \%$ heat-inactivated fetal calf serum and $0.1 \%$ streptomycin/penicillin in standard 297 culture conditions.

298 The human skin fibroblast cell line BJ was cultured in MEM (Sigma, M2279) in the presence of 10\% 299 FBS, 4mM glutamine, and 0.5\% streptomycin/penicillin. All the cells were incubated under standard 300 conditions (humidified air with $5 \% \mathrm{CO} 2$ at $37^{\circ} \mathrm{C}$ ). The cells were passaged at $90 \%$ confluence by 301 washing once with cation-free HBSS followed by a 3 min incubation with trypsin $([0.5 \mu \mathrm{g} / \mathrm{mL}] /$ EDTA $302[0.2 \mu \mathrm{g} / \mathrm{mL}])\left(\right.$ Gibco-BRL, 15400054) solution in HBSS at $37^{\circ} \mathrm{C}$, and transferred to its medium. Prior 303 to seeding at a defined cell concentration, the cells were recovered from the medium by centrifugation 304 and counted.

\subsubsection{Cell viability assays}

307 For these studies, compounds were dissolved in $100 \%$ DMSO at $50 \mathrm{mM}$ as stock solution; then, 308 consecutive dilutions have been done in DMSO (1:1) (in this way DMSO concentration in cell media 309 was always the same); followed by 1:500 dilutions of the solutions of compounds on cell media. The 310 assay was carried out as described by Givens et al. [74]. In brief, MDA-MB231 and MCF7 cells were 311 plated at 5000 cells/well or 10,000 cells/well respectively, in $100 \mu \mathrm{L}$ media in tissue culture 96 well 312 plates (Cultek). BJ cells were plated at 2500 cells per well. After $24 \mathrm{~h}$, medium was replaced by 100 $\mu \mathrm{L} /$ well of serial dilution of drugs. Each point concentration was run in triplicate. Reagent blanks, 
containing media plus colorimetric reagent without cells were run on each plate. Blank values were subtracted from test values and were routinely $5-10 \%$ of uninhibited control values. Plates were incubated for $72 \mathrm{~h}$. Hexosamidase activity was measured according to the following protocol: the media containing the cells was removed and cells were washed once with phosphate buffer saline (PBS) $60 \mu \mathrm{L}$ of substrate solution (p-nitrophenol-N-acetyl- $\beta$-D-glucosamide 7.5mM [Sigma N-9376], sodium citrate $0.1 \mathrm{M}, \mathrm{pH}=5.0,0.25 \%$ Triton $\mathrm{X}-100$ ) was added to each well and incubated at $37^{\circ} \mathrm{C}$ for $1-2 \mathrm{~h}$; after this incubation time, a bright yellow colour appeared; then, plates could be developed by adding $90 \mu \mathrm{L}$ of developer solution (Glycine $50 \mathrm{mM}, \mathrm{pH}=10.4$; EDTA $5 \mathrm{mM}$ ), and absorbance was recorded at $410 \mathrm{~nm}$.

\subsubsection{DNA migration studies}

A stock solution (10 $\mathrm{mM})$ of each compound was prepared in high purity DMSO. Then, serial dilutions were made in MilliQ water (1:1). Plasmid pBluescript SK+ (Stratagene) was obtained using a QIAGEN plasmid midi kit as described by the manufacturer. Interaction of drugs with pBluescript SK + plasmid DNA was analysed by agarose gel electrophoresis following a modification of the method described by Abdullah et al. [75]. Plasmid DNA aliquots $(40 \mu \mathrm{g} / \mathrm{mL})$ were incubated in TE buffer (10mM Tris-HCl, $1 \mathrm{mM}$ EDTA, $\mathrm{pH}$ 7.5) with different concentrations of compounds $1 \mathrm{a}, 1 \mathrm{~b}, 2 \mathrm{a}$ and $3 \mathrm{a}$ ranging from 0 to $200 \mu \mathrm{M}$ at $37^{\circ} \mathrm{C}$ for $24 \mathrm{~h}$. Final DMSO concentration in the reactions was always lower than $1 \%$. For comparison, cisplatin $(1-10 \mu \mathrm{M})$ and ethidium bromide $(\mathrm{EB}, 10 \mu \mathrm{M})$ were used as reference controls. Aliquots of $20 \mu \mathrm{L}$ of the incubated solutions of compounds containing $0.8 \mu \mathrm{g}$ of DNA were subjected to $1 \%$ agarose gel electrophoresis in TAE buffer (40mM Trisacetate, $2 \mathrm{mM}$ EDTA, $\mathrm{pH} 8.0$ ). The gel was stained in TAE buffer containing ethidium bromide $(\mathrm{ET}, 0.5 \mathrm{mg} / \mathrm{mL})$ and visualized and photographed under UV light.

\subsubsection{DNA topoisomerase I and topoisomerase II $\alpha$ inhibition assays Topoisomerase I-based} experiments were performed as described previously [76]. Supercoiled pBluescript DNA, obtained as described above, was treated with Topoisomerase I in the absence or presence of increasing concentrations of compounds 1a, 1b, 2a and 3a. Assay mixtures contained supercoiled pBluescript DNA $(0.8 \mu \mathrm{g})$, calf thymus Topoisomerase I ( 3 units) and compounds $1 \mathrm{a}, 1 \mathrm{~b}, 2 \mathrm{a}$ or $3 \mathrm{a}(0-200 \mu \mathrm{M})$ in $20 \mu \mathrm{L}$ of relaxation buffer Tris- $\mathrm{HCl}$ buffer $(\mathrm{pH} 7.5)$ containing $175 \mathrm{mM} \mathrm{KCl}, 5 \mathrm{mM} \mathrm{MgCl} 2$ and $0.1 \mathrm{mM}$ EDTA. Ethidium bromide $(\mathrm{EB}, 10 \mu \mathrm{M})$ was used as a control of intercalating agents and etoposide $(\mathrm{E}, 100 \mu \mathrm{M})$ as a control of the non-intercalating agent. Reactions were incubated for $30 \mathrm{~min}$ at $37^{\circ} \mathrm{C}$ and stopped by the addition of $2 \mu \mathrm{L}$ of agarose gel loading buffer. Samples were then subjected to electrophoresis and DNA bands stained with ethidium bromide as described above.

To distinguish whether compounds act as Topoisomerase inhibitors or DNA intercalators the conversion of relaxed DNA to a supercoiled state caused by the compounds was analysed in the presence of Topoisomerase I. Relaxed DNA was obtained by incubation of supercoiled DNA with Topoisomerase I as described above. Assay mixtures $(20 \mu \mathrm{L})$ contained: relaxed DNA, Topoisomerase I (3 units) and 
compound $(50 \mu \mathrm{M}$ or $100 \mu \mathrm{M})$. Reactions were incubated 20 min at $37{ }^{\circ} \mathrm{C}$ and stopped as described above. Ethidium bromide $(10 \mu \mathrm{M})$ was used as a control of intercalative drug.

353 The DNA Topoisomerase II $\alpha$ inhibitory activity of the compounds tested in this study was measured as

354 follows. Supercoiled pBluescript DNA was incubated with Topoisomerase II $\alpha$ (Affymetrix) in the

355 absence or presence of increasing concentrations of compounds under analysis. Assay mixtures

356

357

358

359 contained supercoiled pBluescript DNA $(0.3 \mu \mathrm{g})$, Topoisomerase II $\alpha$ (4 units) and the tested compounds $(0-200 \mu \mathrm{M})$ in $20 \mu \mathrm{L}$ of $1 \times$ Topo II reaction buffer (PN73592). Etoposide was used as a control of Topo II $\alpha$ inhibitor. Reactions were incubated for $45 \mathrm{~min}$ at $37^{\circ} \mathrm{C}$ and stopped by the addition of $2 \mu \mathrm{L}$ of agarose gel loading buffer. Samples were then subjected to electrophoresis and DNA bands stained with ethidium bromide as described before.

\subsubsection{Cathepsin B inhibition assay}

The colorimetric cathepsin B assay was performed as described by Casini et al. [77] with few modifications. Briefly, the reaction mixture contained 100mM sodium phosphate (pH 6.0), 1mM EDTA and $200 \mu \mathrm{M}$ sodium N-carbobenzoxy-L-lysine p-nitrophenyl ester as the substrate.

To have the enzyme catalytically active before each experiment the cysteine in the active site was reduced by treatment with dithiothreitol (DTT). For this purpose, $5 \mathrm{mM}$ DTT was added to the cathepsin B sample, before dilution, and incubated $1 \mathrm{~h}$ at $30^{\circ} \mathrm{C}$. To test the inhibitory effect of the compounds on cathepsin B, activity measurements were performed in triplicate using fixed concentrations of enzyme $(500 \mathrm{nM})$ and substrate $(200 \mu \mathrm{M})$. The compounds were used at concentrations ranging from 5 to 100 $\mu \mathrm{M}$. Previous to the addition of substrate, cathepsin B was incubated with the different compounds at 25 ${ }^{\circ} \mathrm{C}$ for $2 \mathrm{~h}$. The cysteine proteinase inhibitor E-64 was used as a positive control of cathepsin B inhibition. Complete inhibition was achieved at $10 \mu \mathrm{M}$ concentration of E-64. Activity was measured over $90 \mathrm{~s}$ at $326 \mathrm{~nm}$ on a UV-spectrophotometer.

6




\subsection{Synthesis and characterization}

3.1.1. Synthesis of the ligands

387

The new carbazole derivatives: 9-methyl-3-(2-thiazolyl)-9H-carbazole (1a) and 9-methyl-3-(2-thienyl)$9 \mathrm{H}$-carbazole $(1 \mathrm{~b})$ were prepared from commercially available carbazole in a three-step-sequence of reactions (Scheme 1), that involved the iodination of the 9H-carbazole [63] followed by the alkylation to produce the 3-iodo-9-methyl-9Hcarbazole [78], that later on reacted with either 2-(tributylstannyl) thiazole (for 1a) [79,80] or 2-(tributylstannyl)thiophene (for 1b) via Stille coupling reaction [81] to produce the final products. All compounds were entirely characterized by $1 \mathrm{H} N M R$ and $13 \mathrm{C}\{1 \mathrm{H}\} \mathrm{NMR}$ spectroscopies, mass spectrometry and elemental analyses.

The crystal structure of compound 1a (Fig. 3) confirmed the presence of the thiazolyl group on position 3. In compound 1a, the nitrogen atom of the thiazolyl unit (N1) is on the same side as the Me group. As a consequence of this arrangement of groups, the N1 atom is proximal to the hydrogen atom $\mathrm{H} 12$ of the carbazole unit while the $\mathrm{S} 1$ atom is relatively close to the $\mathrm{H} 4$ atom. The distances N1 $\cdots \mathrm{H} 12(2.580 \AA)$

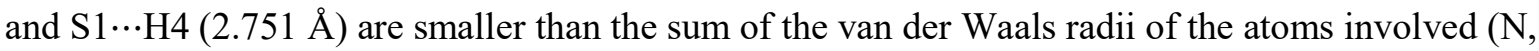
$1.55 \AA ; \mathrm{H}, 0.95 \AA$ and $\mathrm{S}, 1.85 \AA$ ) [82-87]. Thus suggesting the existence of non-conventional $\mathrm{CeH} \cdots \mathrm{N}$ and $\mathrm{CeH} \cdots \mathrm{S}$ intramolecular hydrogen bonds [88], similar to those found in most 2-phenylthiazole derivatives [82-86,89-92].

The thiazolyl group is planar and slightly twisted (ca. $13.9^{\circ}$ ) in relation to the main plane of the carbazole array. In the crystal, the relative orientation of the molecules (Fig. 4, A) allows $\pi \cdots \pi$ interactions between the heterocyclic array of a unit at $(\mathrm{x}, \mathrm{y}, \mathrm{z})$ and the substituted phenyl ring of another one at $(1+x, y, z)$ (the distance between the centroids of these rings is $3.90 \AA)$. In addition, one of the hydrogen atoms of the methyl group is at only $2.77 \AA$ from the centroid of the phenyl ring of a parallel unit, indicating the existence of intermolecular $\mathrm{CeH} \cdots \pi$ contacts. As a consequence of this, the assembly of the molecules results in pillars (Fig. 4, A). These structural units are connected by additional $\mathrm{CeH} \cdots \pi$ short contacts (Fig. 4, B) involving the $\mathrm{H} 3$ atom of the heterocyclic units in one of the pillars and the centroids of the thiazolyl groups of another one.

\subsubsection{Coordination capability of the new hybrid carbazoles $1 \mathrm{a}$ and $1 \mathrm{~b}$ In view of their potential} biological activities (i.e. anticancer, antibacterial), we decided to evaluate the coordination abilities of the new carbazoles in front of the $\mathrm{Pd}(\mathrm{II})$ and $\mathrm{Pt}(\mathrm{II})$ ions. In a first stage, we selected ligand 1a and studied its reactivity with [MCl2(dmso)2] \{transfor $\mathrm{M}=\mathrm{Pd}$ or cis- for $\mathrm{M}=\mathrm{Pt}$ \} or $\mathrm{Na}$ [PdCl4] under different experimental conditions [Table 2 (entries I-VI) and Scheme 2]. When trans-[PdCl2(dmso)2] was treated with the equimolecular amount of ligand 1a or a two-fold excess in refluxing methanol for 1 $\mathrm{h}$, a pale yellowish precipitate (hereinafter referred to as $2 \mathrm{a}$ ) was formed with a yield of $28 \%$ in the case of using a molar ratio of 1:1 (Table 2, entry I). Elemental analyses of 2a and NMR characterization 
agreed with those expected for trans-[PdCl2(1a)2]. Molecular models suggest that a cisdisposition of the ligands will introduce strong steric hindrance between the two close carbazole ligands 1a and on this basis, we assume that the isolated solid is the trans- isomer. Compounds [PdX2(L)2] with bulky monodentate $\mathrm{N}$-donor ligands, including heterocycles such as benzothiazolyl derivatives, tend to adopt this configuration in solution and in the solid state [93-95]. Compound 2a is a stable solid at room temperature and exhibits low solubility in $\mathrm{CHCl} 3$ or $\mathrm{CH} 2 \mathrm{Cl} 2$. Compound 2a can be obtained with a higher yield of $82 \%$ and at room temperature using $\mathrm{Na} 2[\mathrm{PdCl} 4]$, instead of the trans-[PdCl2(dmso)2], a two-fold excess of carbazole 1a and methanol as solvent (Table 2, entry II). In order to compare the effect of the binding of the M(II) ion to the carbazole 1a on the anticancer activity, we also studied the reactivity of 1a in front of $\mathrm{Pt}(\mathrm{II})$. Treatment of equimolar amounts of 1a and cis- $[\mathrm{PtCl} 2(\mathrm{dmso}) 2]$ in methanol (HPLC grade) under reflux for $1 \mathrm{~h}$, followed by the work-up of a SiO2 column chromatography gave a yellowish solid (3a) (Table 2, entry III and Scheme 2). Its elemental analyses were consistent with those expected for [PtCl2(1a)(dmso)]. Moreover, the position of the singlet observed in the $195 \mathrm{Pt}\{1 \mathrm{H}\}-\mathrm{NMR}$ spectrum of $3 \mathrm{a}(\delta=-2983 \mathrm{ppm})$ agrees with those of related $\mathrm{Pt}(\mathrm{II})$ complexes with a "PtCl2(Nheterocycle)(Sdmso)" core [57-59,96-98]. Its 1H-NMR spectrum (Fig. S2) showed two singlets of relative intensities 1:2 in the high field region. The less intense one is assigned to the methylic protons of the ligand at $\delta=4.0 \mathrm{ppm}$; while the other corresponds to the six protons of the dmso ligand. This finding is characteristic of trans- isomers of [ $\mathrm{PtCl} 2(\mathrm{~N}$-donor ligand)(dmso)] [57-59,96-98], thus indicating that compound 3a is trans-[PtCl2(1a)(dmso)]. It should be noted that when the reaction was performed using longer reaction times no evidences of the formation of any other Pt(II) compound were detected by $1 \mathrm{H}-\mathrm{NMR}$. Since it is well-known that the presence of a base such as NaOAc and mixtures of toluene / methanol $(5: 1)$ as solvent may induce the formation of the cis- isomers of compounds [ $\mathrm{PtCl}$ ( $\mathrm{N}$-donor ligand)(dmso)] or even cycloplatinated complexes [57-60,96-101], we also investigated whether for ligand 1a the addition of $\mathrm{NaOAc}$ could affect the nature of the final $\mathrm{Pt}(\mathrm{II})$ product. When equimolar amounts of 1a, cis-[PtCl2(dmso)2] and $\mathrm{NaOAc}$ were refluxed in a mixture of toluene: methanol $(5: 1)$ for $72 \mathrm{~h}$ (Table 2, entry VI and Scheme 2), the 1H-NMR spectrum of the raw material in CDCl3 at $298 \mathrm{~K}$ (Fig. S4) revealed the coexistence of $3 a$ and a minor product (hereinafter referred to as 4a). The work-up of a column chromatography allowed us to isolate complex $3 \mathrm{a}$ and a solid containing a mixture of $3 \mathrm{a}$ and 4a. The 195Pt $\{1 \mathrm{H}\}$ NMR spectrum of the solid dissolved in CDCl3 at $298 \mathrm{~K}$ (Fig. S1, A) showed two singlets (one at $\delta=-2980 \mathrm{ppm}$ (due to 3a) and the other at $\delta=-2932 \mathrm{ppm}$ assigned to compound 4a). Their chemical shifts suggest that the environment of the Pt(II) atoms in $3 \mathrm{a}$ and $4 \mathrm{a}$ should be very similar. Moreover, the separation between the two singlets (ca. $41 \mathrm{ppm}$ ), falls in the typical range reported for trans- and cis- isomers of [Pt(N-donor)Cl2(dmso)] compounds. Besides that, its 1H-NMR spectrum (Fig. S1, B) revealed that for 4a the resonances due to the protons of the dmso ligand appeared as two singlets, in good agreement with a cisdisposition of the $\mathrm{Cl}$ - ligands. On these basis we assumed 
that $4 \mathrm{a}$ is the cis- isomer of [ $\mathrm{PtCl} 2(1 \mathrm{a})(\mathrm{dmso})]$. Unfortunately, attempts to isolate $4 \mathrm{a}$ in its pure form, by fractional crystallization or subsequent column chromatography failed.

458 Comparison of 1 H-NMR spectra of the new complexes (2a, 3a and 4a) with that of the parent ligand 1a reveals that the resonances due to the $\mathrm{H} 2$ and $\mathrm{H} 4$ protons of the carbazole array were highly affected by the binding of the nitrogen to the Pt(II) ion. It should be noted that: a) the formation of the Pt$\mathrm{N}($ thiazole) bond requires the cleavage of the intramolecular $\mathrm{C} 11 \mathrm{eH} 12 \cdots \mathrm{N}$ hydrogen bond, $\mathrm{b}$ ) in cis- and trans- isomers of $[\mathrm{PtCl} 2(\mathrm{~N}$-heterocycle $)(\mathrm{dmso})]$ complexes, the heterocycle is orthogonal to the main coordination plane of the ligand [57-60,93,102,103], and c) frequently ancillary ligands ( $\mathrm{Cl}-$ or dmso) are involved in additional $\mathrm{CeH} \cdots \mathrm{X}[\mathrm{X}=\mathrm{Cl}$ or $\mathrm{O}(\mathrm{dmso})]$ contacts with the neutral $\mathrm{N}$-donor ligand $[93,102,103]$. All these findings could explain the variations observed in the chemical shifts of the protons adjacent to position 3 in complexes $3 \mathrm{a}$ and $4 \mathrm{a}$. In order to compare the potential coordination ability of the two new carbazoles, the reactivity of the thienyl derivative $1 \mathrm{~b}$ with [MCl2(dmso)2] and $\mathrm{Na} 2[\mathrm{PdCl} 4]$ was studied under identical conditions as for 1a (described above and shown in Scheme 2) and using identical conditions as those shown in Table 2 (entries I - IV). However, none of these studies allowed us neither the isolation or even the detection by 1H-NMR of any $\mathrm{Pd}(\mathrm{II})$ or $\mathrm{Pt}(\mathrm{II})$ complex, thus suggesting that thiazolesubstituted carbazole 1a has a greater coordination ability than the thienyl analogue $1 \mathrm{~b}$.

\subsection{Electronic spectra and optical properties} Absorption spectra of $\mathrm{CH} 2 \mathrm{Cl} 2$ solutions of $1 \mathrm{a}$ and $1 \mathrm{~b}$ at $298 \mathrm{~K}$ (Table 3 and Fig. S5, A) showed two intense bands in the range $250-450 \mathrm{~nm}$ that are characteristic of carbazoles. The corresponding UV-vis spectra of the complexes 2a and 3a (Fig. S5, B and Table 3) exhibited two intense absorption bands in the range $300 \leq \lambda<350 \mathrm{~nm}$. One of them shifted to lower energies in relation to the free ligand being for the Pt(II) complex (3a) the magnitude of the shift bigger than for the Pd(II) complex 2a (Table 3). These findings suggest that this absorption band is due to a metal perturbed intraligand electronic transition (MPILET). The second absorption band, at higher energies, is practically coincident with that of the free ligand. The spectra of compounds $2 \mathrm{a}$ and $3 \mathrm{a}$ (Fig. S5, B) also exhibited an additional and poorly resolved absorption band at lower wavelengths $[280 \leq \lambda<290 \mathrm{~nm}]$.

The emission spectra of $1 \mathrm{a}, 1 \mathrm{~b}, 2 \mathrm{a}$ and $3 \mathrm{a}$ were recorded in $\mathrm{CH} 2 \mathrm{Cl} 2$ solution at $298 \mathrm{~K}$. Upon excitation at $\lambda \mathrm{exc}=300 \mathrm{~nm}$, the free ligands $1 \mathrm{a}$ and $1 \mathrm{~b}$ exhibited emission bands in the range $370-395 \mathrm{~nm}$ (Fig. S6 and Table 3). The thienyl-based derivative $1 \mathrm{~b}$ showed a bathochromic shift of the wavelength of maximum emission of $10 \mathrm{~nm}$ in comparison to the thiazolyl-based ligand 1a, according to the strongest electron-donating character of the thienyl unit. It should be noted that the quantum yield of 1a (Table 3) is significantly higher than that of $1 \mathrm{~b}$. Complexes $2 \mathrm{a}$ and $3 \mathrm{a}$ exhibited also emission bands consistent with that of ligand 1a, but their fluorescence quantum yields [104] decreased considerably in relation to 
494 In order to elucidate the effect produced by the thiazolyl or thienyl groups of compounds $1 \mathrm{a}$ and $1 \mathrm{~b}$ on the electronic delocalization, computational calculations based on the density functional theory (DFT) methodology were undertaken [68]. Calculations were carried out using the B3LYP hybrid functional $[69,70]$ and the $6-31 \mathrm{G}^{*}$ basis set $[72,73]$ implemented in the Gaussian03 program [71]. In a first stage, geometries of compounds $1 \mathrm{a}$ and $1 \mathrm{~b}$ were optimized without imposing any restriction. Final atomic coordinates for the optimized geometries are included as supplementary information (Tables S1-S2). Bond lengths and angles of the optimised geometry of 1a were consistent with those obtained from the X-ray studies (the differences did not clearly exceed $3 \sigma$ ) and those of $1 \mathrm{~b}$ are in the range reported for related carbazoles with mono or polythienyl units on position $3[50-52,93,103]$. Molecular orbital (MO) calculations of the optimized geometries revealed that highest occupied molecular orbital (HOMO) (Fig. 5) of $1 \mathrm{a}$ and $1 \mathrm{~b}$ are very similar except for a tiny difference in the contribution of the atomic orbitals of the sulphur atom. The LUMO (Fig. 5) of 1a is mainly centred on the thiazolyl unit and two of the rings of the carbazole; while in $1 \mathrm{~b}$, the contribution of the thienyl decreases in relation to that of the thiazole in 1a. Moreover, the HOMO-LUMO gap $(\Delta \mathrm{E})$ of $1 \mathrm{~b}(4.32$ $\mathrm{eV})$ is higher than for $1 \mathrm{a}(4.14 \mathrm{eV})$. These findings suggest that the replacement of the thiazolyl ring of $1 \mathrm{a}$ by the thienyl in $1 \mathrm{~b}$ reduces the electronic delocalization mentioned above. In the optimized geometry of $1 \mathrm{~b}$ the intramolecular separation between the $\mathrm{S} 1$ atom and the hydrogen

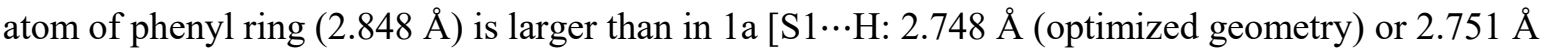
(from the crystal structure)] and the angle formed by the heterocycle and the carbazole is $30.3^{\circ}$ bigger than in 1a. Since it is well-known that deviations from planarity affects the electronic delocalization, the properties of the compounds and their potential utility, we also calculated the energy of the molecules for different orientations of the attached heterocycle versus the carbazole unit using molecular mechanics. These arrangements were generated by modifying the torsion angle defined by the set of atoms S1-C2'-C3-C4 (hereinafter referred to as $\varphi$ ) from $0^{\circ}$ to $360^{\circ}$. The results shown in Fig. 6, reveal that for $1 \mathrm{a}$ the minimum energy corresponds to $\varphi$ values in the ranges $\left(0^{\circ} \leq \varphi \leq 16^{\circ}\right.$ and $\left.344^{\circ} \leq \varphi \leq 360^{\circ}\right)$, that is to say close to co-planarity, similar to that found in the crystal structure $\varphi=13.5^{\circ}$ and with the $\mathrm{S} 1$ atom and NMe group located in opposite sides. The energy barrier to achieve an orthogonal arrangement of the thiazole $\left(\varphi=90^{\circ}\right.$ or $\left.270^{\circ}\right)$ is rather high $(9.1 \mathrm{~kJ} / \mathrm{mol})$. The conformer with the $\mathrm{N} 1$ and $\mathrm{N} 2$ atoms on opposite sides, $\left[\varphi\right.$ values between $164^{\circ}$ and $196^{\circ}$ ] is slightly less stable than for $\varphi=0 \pm 16^{\circ}$ (Fig. 6). The differences between the energies of both conformers determined from molecular mechanics calculations and DFT are 0.4 and $0.5 \mathrm{Kcal} / \mathrm{mol}$, respectively.

526 In contrast with the results obtained for $1 \mathrm{a}$, in $1 \mathrm{~b}$ the most favourable orientation of the thienyl unit is far away from co-planarity and corresponds to $\varphi$ values in the ranges $128^{\circ}-133^{\circ}$ and $232^{\circ}-237^{\circ}$. The energy barriers to achieve coplanar arrangements (Fig. 6) are smaller than that obtained for 1a (9.1 
a smaller energy income, is more likely to occur than that of the thiazolyl ring of 1a. In addition, time dependent DFT (TD-DFT) calculations were performed to achieve the assignment of the bands observed in the UV-vis spectra (Table S4 and Fig. S7).

Besides that and in order to compare the stability of the two isomers of the platinum(II) complexes (3a and 4a), we optimized their geometries (Tables S5 and S6) and afterwards we calculated their relative energies. The results revealed (Table S7) that in vacuum the transisomer ( $3 \mathrm{a}$ ) is ca. $4.3 \mathrm{kcal} / \mathrm{mol}$ more stable than $4 \mathrm{a}$ (cis- isomer), but in methanol $(\mathrm{MeOH})$ the difference between their calculated free energies decreased to $-0.30 \mathrm{kcal} / \mathrm{mol}$. This may explain the formation of both isomers in a similar molar ratio.

\subsection{Biological studies}

\subsubsection{Antiproliferative assay}

We have evaluated the cytotoxic activity of ligands $1 \mathrm{a}$ and $1 \mathrm{~b}$ and the new complexes $2 \mathrm{a}$ and $3 \mathrm{a}$ in front of the colon cell line HCT116 and two breast cancer cell lines [the triple negative (ER, PR and no HER2 over expression) MDA-MB231 and the MCF7]. The effects of the new products on the growth of the three cell lines and that of cisplatin, used as positive control, were assessed after $72 \mathrm{~h}$ and the results are presented in Table 4 and Fig. 7.

The comparison of the in vitro cytotoxic activities of the free carbazoles $1 \mathrm{a}$ and $1 \mathrm{~b}$ in the HCT116 cell line revealed that the replacement of the thienyl ring (in 1b) by the thiazolyl unit of 1a produced a significant enhancement of the cytotoxic potency. This trend is practically identical to those observed in the two breast (MDA-MB231 and the MCF7) cancer cell lines and could be attributed to several factors. One of these could be the lipophilicity that, as shown in Table 4, is expected to be slightly different for the two systems. It should be noted that in the MCF7 cell line ligand 1a is (ca. 9.5 times) more potent than cisplatin, the non-alkylated 9H-carbazole (IC50 $>40 \mu \mathrm{M}$ ) and similar to doxorubicin (IC50=2.3 $\mu \mathrm{M}$ [105] or $2.43 \pm 0.24 \mu \mathrm{M}[106])$.

In order to compare the effect produced by the binding of the $\mathrm{Pd}(\mathrm{II})$ or $\mathrm{Pt}(\mathrm{II})$ we also examined the effect produced by the complexes $2 \mathrm{a}$ and $3 \mathrm{a}$ on identical cell lines. As shown in Table 4 and Fig. 7, the Pd(II) complex 2a did not show any relevant antiproliferative activity (IC50 $>100 \mu \mathrm{M})$ in the HCT116 and MDA-MB231 cell lines. In the MCF7 it was more active, but its potency was close (IC50=24 \pm 2 $\mu \mathrm{M}$ ) to that of cisplatin (IC50=19 $\pm 4.5 \mu \mathrm{M}$ ). In contrast, the Pt(II) complex (3a) exhibited a higher inhibitory growth effect, being 9 times more potent than the reference drug in the MCF7 breast cancer cell line.

It is well-known that the preparation of new products with improved cytotoxic potency is not the unique requirement in medicinal chemistry and drug design, other factors such as the lipophilicity that contributes to the ADMET (absorption, distribution, metabolism excretion and toxicity) properties of drugs also plays a crucial role. Nowadays, the lipophilic efficiency (LipE) index [107-110] that includes 
lipophilicity and potency is becoming more and more popular in drug design and optimization, because it allows to normalize the observed potency with changes in the lipophilicity.

568 In view of this, we calculated the Clog P values for the new compounds and their LipE index in the MCF7 cell line. The results (Table 4) reveal that for the compounds characterized in this work the LipE index increases as follow $2 \mathrm{a} \ll 1 \mathrm{~b}<1 \mathrm{a} \leq 3 \mathrm{a}$. The $\mathrm{Pd}(\mathrm{II})$ complex $2 \mathrm{a}$ that shows low solubility it is simultaneously the most lipophilic and the less potent compound of the series. In contrast with these results, for the carbazole-thiazole ligand 1a and its trans-[PtCl2(1a)(dmso)] complex 3a there is an effective combination of their cytotoxic potency in MCF7 and lipophilicity, and on these basis they are promising scaffolds in the search of optimized drugs. Chemical modifications of the core of ligand $1 \mathrm{a}$, its binding to the $\mathrm{Pt}(\mathrm{II})$ atom or even changes on the ancillary ligands bound to it in 3a may allow to tune the lipophilicity and to improve the lipophilic efficiency.

\subsubsection{Additional studies to elucidate the mechanism of action}

In the majority of the described cases of cytotoxic carbazoles, they act as DNA-intercalators or as Topoisomerase I/II (or telomerases) inhibitors [24,111], although other mechanisms of action involving different targets \{i.e. estrogen receptors (ER) or cyclin dependent kinases (CDK), among others\} have also been postulated [22-26,112]. To examine whether the presence of the thiazole (in 1a) or the thienyl unit (in 1b) in the free ligand and the binding of 1a to the Pd(II) or Pt(II) ions in complexes 2a and 3a, could have an important role in the mechanism of action, additional experiments were performed. To elucidate whether compounds 1a, 1b, 2a and 3a act as DNA intercalators or as Topoisomerase I or II inhibitors, three different sets of experiments were undertaken. In a first stage it was examined if the new compounds could induce changes in the electrophoretic mobility of the supercoiled closed form (ccc) of pBluescript SK+ plasmid DNA. For DNA migration studies, the plasmid was incubated with compounds $1 \mathrm{a}, 1 \mathrm{~b}, 2 \mathrm{a}$ and $3 \mathrm{a}$ at increasing concentrations ranging from 0 to $200 \mu \mathrm{M}$. For comparison purposes, incubation of DNA with cisplatin or ethidium bromide (EB) was also performed. As expected, cisplatin greatly altered the electrophoretic mobility of pBluescript DNA at all concentrations tested. As depicted in Fig. 8, the free ligands (1a and $1 \mathrm{~b}$ ) and the Pd(II) compound (2a) were not effective. Only the Pt(II) complex (3a) produced a significant effect on the electrophoretic mobility of native pBluescript DNA at concentrations $>100 \mu \mathrm{M}$. Secondly, a Topoisomerase based gel assay was performed to evaluate the ability of compounds $1 \mathrm{a}, 1 \mathrm{~b}, 2 \mathrm{a}$ and $3 \mathrm{a}$ to intercalate into DNA or to act as DNA Topoisomerase I inhibitors. For that, supercoiled pBluescript plasmid DNA was incubated with are presented in Fig. 9, where ethidium bromide (EB) was used as an intercalator control. The analysed compounds did not prevent unwinding of DNA indicating that they are neither intercalators nor Topoisomerase I inhibitors. 
602 As mentioned above, another important target for anticancer agents is the Topoisomerase II, which is

603 associated with solving the topological constraints of DNA by transiently cleaving both strands of the

604 double helix $[24,111]$. In humans there are two Topoisomerase II isoenzymes, II $\alpha$ and II $\beta$. Here we

605 study the capability of compounds $1 \mathrm{a}, 1 \mathrm{~b}, 2 \mathrm{a}$ and $3 \mathrm{a}$ as catalytic inhibitors of Topoisomerase II $\alpha$. The

606 inhibitory activity was evaluated by measuring the extent of enzyme mediated relaxed DNA after

607 treatment with $100 \mu \mathrm{M}$ of $1 \mathrm{a}, 1 \mathrm{~b}, 2 \mathrm{a}$ and $3 \mathrm{a}$ compounds. Only the Pd(II) complex 2a showed at this

608 concentration inhibitory activity (Fig. 10A). The inhibitory effect of $2 \mathrm{a}$ was further examined at different

609 concentrations, from 50 to $200 \mu \mathrm{M}$. As it is shown in Fig. 10B, compound 2a showed inhibition at 100

$610 \mu \mathrm{M}$ but not at $50 \mu \mathrm{M}$.

611 Other mechanism of action implies Cathepsin B, which is a cysteine metaloprotease that could be

612 involved in metastasis, angiogenesis and tumour progression. Examples of $\mathrm{Pd}(\mathrm{II})$ and $\mathrm{Pt}(\mathrm{II})$ complexes

613 as inhibitors of Cathepsin B have been reported [113]. However, none of the new compounds presented

614 in this work (1a, 1b, 2a and 3a) inhibited the enzyme activity at $100 \mu \mathrm{M}$ concentration.

615 Overall the biological studies undertaken with the new compounds 1a, 1b, 2a and 3a provide conclusive

616 evidences. The DNA migration studies revealed that only Pt(II) complex (3a) modifies the

617 electrophoretic mobility of the plasmid in a similar way as cisplatin but at higher concentrations.

618 Experimental results also revealed that neither compounds 1a, with higher cytotoxic activity than

619 cisplatin in the tested cancer lines HCT116 and MCF7, nor compounds 1b or 2a operate as intercalators

620 and none of them are inhibitors of Topoisomerase I or cathepsin B. However, the Pd(II) complex (2a)

621 inhibits the activity of Topoisomerase II $\alpha$ (at $200 \mu \mathrm{M}$ concentration).

622 All the new compounds show lower toxicity on the normal and nontumoral human skin fibroblast BJ

623 cell line than cisplatin (Table 4). Among the new compounds, 1a and its Pt(II) complex 3a are the most

624 active in the assayed HCT116, MDA-MB231 and MCF7 cancer cell lines. Moreover, compound 1a,

625 clearly more potent than $3 \mathrm{a}$, has additional interest because it does not contain $\mathrm{Pt}(\mathrm{II})$ and consequently

626 might not produce the typical and undesirable side effects of conventional Pt(II)-based drugs. In

627 addition, compound 1a shows a remarkable high stability in the solid state and also in dmso or in

628 mixtures dmso: D2O (Figs. S9-S15) at $298 \mathrm{~K}$. These findings enhance the interest and relevance of

629 carbazole 1a for further and additional biological studies.

630

631 
634 Here we have presented two new N-methylated and 3-substituted carbazoles with a thiazolyl (1a) or a

635 thienyl (1b) unit and comparative studies of their properties and reactivity in front of $\mathrm{Na}$ [PdCl4] or

$636[\mathrm{MCl} 2$ (dmso)2] \{trans- for $\mathrm{M}=\mathrm{Pd}$ or cis- for $\mathrm{M}=\mathrm{Pt}\}$ and biological activities. The obtained results

637 proved that compound $1 \mathrm{a}$ is clearly more reactive than $1 \mathrm{~b}$ and has a greater coordination capability

638 towards the $\mathrm{Pd}(\mathrm{II})$ and $\mathrm{Pt}(\mathrm{II})$ ions, leading to trans-[PdCl2(1a)2] (2a) and the geometrical isomers \{trans-

639 (3a) or cis-(4a)\} of [PtCl2(1a)(dmso)]. DFT studies confirmed the different reactivity of $1 \mathrm{a}$ and $1 \mathrm{~b}$ and

640 the formation of the isomers $3 \mathrm{a}$ and $4 \mathrm{a}$.

641 In vitro studies on the cytotoxic activity of compounds $1 \mathrm{a}, 1 \mathrm{~b}, 2 \mathrm{a}$ and $3 \mathrm{a}$ in the cancer cell lines

642 (HCT116, MDA-MB231 and MCF7) and in the normal and non-tumoral human skin fibroblasts BJ cell

643 line show that: a) the replacement of the thiazole (of 1a) by the thienyl (to give 1b) reduces the

644 inhibitory growth effect, b) the binding of 1a to the Pt (II) atom (3a) reduces its cytotoxic activity, c)

645 compound 2a is less active than the Pt(II) complex $3 \mathrm{a}$ and d) all compounds are less toxic than cisplatin

646 in the BJ cell line. Additional biological studies revealed that: a) only the Pt(II) complex (3a) induced

647 significant changes on the electrophoretic mobility of the pBluescript DNA, but at higher concentrations

648 than the cisplatin and b) neither the ligands (1a and 1b) nor the Pd(II) (2a) or Pt(II) complex (3a) acted

649 as intercalators or inhibitors of Topoisomerase I or Cathepsin B. However, the Pd(II) complex (2a) with

650 an inhibitory growth activity in the MCF7 cell line similar to that of cisplatin inhibited the

651 Topoisomerase II $\alpha$ activity. These findings suggest that the binding of the $\mathrm{Pd}(\mathrm{II})$ or the $\mathrm{Pt}(\mathrm{II})$ to the

652 carbazole 1a not only produces significant changes in their cytotoxic activity but also on their

653 mechanism of action.

654 To sum up, among the new compounds, 1a with high stability, low toxicity, potent cytotoxic activity and 655 photophysical properties is an excellent candidate for further studies on: a) their effect on a wider panel 656 of cancer cell lines, b) its mechanism of action, c) its potential use in combined therapies even in 657 photodynamic therapy, and d) other biological activities (i.e. antibacterial, antifungal, etc.) maybe 658 relevant in new drug design and development. 


\section{ACKNOWLEDGEMENTS}

661

662 This work was supported by the Ministerio de Ciencia e Innovación of Spain (MICINN) (Grant numbers 663 CTQ2015-65040-P and CTQ2015- 65770-P MINECO/FEDER).

664 
666 Tables containing: final atomic coordinates of the optimised geometries of carbazoles 1a and 1b (Tables

667 S1 and S2, respectively), calculated energies of the HOMO and LUMO orbitals, energy gaps for the new 668 carbazoles and calculated values of the Mulliken charges of selected atoms (Table S3), summary of the 669 results obtained from the computational studies showing electronic transitions with greater contributions 670 in the absorption bands for $1 \mathrm{a}$ and $1 \mathrm{~b}$ (Table S4), calculated final atomic coordinates for isomers $3 \mathrm{a}$ and $6714 a$ (Tables S5-S6) and calculated energies for 3a and 4a (Table S7) and additional Figures (Figs. S1672 S12) showing: the 1H-NMR spectrum of compound 3a (Fig. S2); an expansion of the 1H-NMR

673 spectrum of the raw material obtained after $24 \mathrm{~h}$ under reflux, showing the presence of complex $3 \mathrm{a}$ and 674 another minor product (Fig. S3); the 1H-NMR spectrum of the crude material obtained after $72 \mathrm{~h}$ that 675 shows the coexistence of $3 \mathrm{a}$ and an additional product 4a (Fig. S4); The 195Pt $\{1 \mathrm{H}\}$ and 1H-NMR 676 spectra of the mixture of the two isomers of [PtCl2(1a)(dmso)] \{trans- (3a) and cis-(4a)\}, isolated from 677 the column (Fig. S1); UV-Vis spectra of compounds 1a, 1b, 2a and 3a (Fig. S5), emission spectra of 678 compounds 1a, 1b, 2a and 3a (Fig. S6); calculated absorption spectra of compounds 1a and 1b (Fig. S7); 679 the HOMO-1 and LUMO+1 orbitals for carbazoles 1a and 1b (Fig. S8); Figures (Figs. S9-S12);

680 showing the 1H-NMR spectra of a freshly prepared solution of compound 1a in dmso-d6 (Fig. S9) or in 681 mixtures dmso-d6: D2O (from 4:1 to 1:1) (Figs. S10-S12) after several periods of storage at $298 \mathrm{~K}$; the 682 1H-NMR spectra of a freshly prepared solution of compounds $1 \mathrm{~b}, 2 \mathrm{a}$ and $3 \mathrm{a}$ in dmso-d6 after several 683 periods of storage at $298 \mathrm{~K}$ (Figs. S13-S15); and ESI-MS spectra of compounds 1a, 1b and 3a (Figs. 684 S16-S18). Supplementary data to this article can be found online at 685 https://doi.org/10.1016/j.jinorgbio.2018.03.008. 


\section{REFERENCES}

688 [1] Cancer Facts \& Figures 2017, American Cancer Society, 2017, http://www.cancer.

689 org/research/cancerfactsstatistics/cancerfactsfigures2017/index , Accessed date: May 2017.

690

[2] Cancer statistics center, American Cancer Society, https://cancerstatisticscenter. cancer.org/?_ga=1.48498790.1307978637.1460725255\#/, (2017), Accessed date: May 2017.

692

[3] A.B. Ryerson, C.R. Eheman, S.F. Altekruse, J.W. Ward, A. Jemal, R.L. Sherman, S.J. Henley, D. Holtzman, A. Lake, A.-M. Noone, R.N. Anderson, J. Ma, K.N. Ly, K.A. Cronin, L. Penberthy, B.A. Kohler, Cancer 122 (2016) 1312-1337.

695

[4] Updated Information on Colorectal and Breast Cancer can be Obtained from the American Cancer Society, Atlanta, Georgia, USA (http://www.cancer.org/acs) Through (a) www.cancer.org/acs/groups/content/documents/document/acspc- 042280.pdf and (b) www.cancer.org/acs/groups/content/documents/document/ acspc-04638.pdf (for Colorectal Cancer and Breast Cancer, Respectively) (2017) (accessed May 2017).

700 [5] G.F. Weber, Molecular Therapies of Cancer, Springer, Germany, 2015.

[6] A.C. Flick, H.X. Ding, C.A. Leverett, R.E. Kyne Jr., K.K.-C. Liu, S.J. Fink, C.J. O'Donnell, Bioorg. Med. Chem. 24 (2016) 1937-1980.

[7] N.A. Meanwell, Chem. Res. Toxicol. 29 (2016) 564-616. $559-568$.

706

[9] E.A.G. Blomme, Y. Will, Chem. Res. Toxicol. 29 (2016) 473-504.

707

[10] S.A. McKie, Future Med. Chem. 8 (2016) 579-602.

708

[11] I. Ali, M.N. Lone, Z.A. Al-Othman, A. Al-Warthan, M.M. Sanagi, Curr. Drug Targets 16 (2015) 711-734.

[12] A.R. Katritzky, C.A. Ramsden, E.F.V. Scriven, R.J.K. Taylor (Eds.), Comprehensive Heterocyclic Chemistry III, Elsevier, Oxford (UK), 2008. 
[14] A.F. Pozharskii, A.T. Soldatenkov, A.R. Katritzky, Heterocycles in Life and Society: An Introduction to Heterocyclic Chemistry, Biochemistry and Applications, second ed., WileyVCH, Weinheim (Germany), 2011.

[15] J.A. McCleverty, T.J. Meyer (Eds.), Comprehensive Coordination Chemistry II: From Biology to Nanotechnology, Elsevier, Amsterdam, 2003.

[16] R.H. Crabtree, D.M.P. Mingos (Eds.), Comprehensive Organometallic Chemistry III, second ed., Elsevier, Oxford, UK, 2007.

[17] G. Wilkinson, R.D. Gillard, J.A. McCleverty (Eds.), Comprehensive Coordination Chemistry: The Synthesis, Reactions, Properties and Applications of Coordination Compounds, Pergamon Press, Oxford, UK, 1987.

[18] J.J. Li, Heterocyclic Chemistry in Drug Discovery, John Wiley \& Sons, Hoboken, USA, 2013.

[19] T.Y. Zhang, Chapter one - the evolving landscape of heterocycles in drugs and drug candidates, in: E.F.V. Scriven, C.A. Ramsden (Eds.), Advances in Heterocyclic Chemistry, 121 Academic Press, 2017, pp. 1-12.

A. Gomtsyan, Chem. Heterocycl. Compd. 48 (2012) 7-10.

[21] P. Martins, J. Jesús, S. Santos, L.R. Raposo, C. Roma-Rodrigues, P.V. Baptista, A.R. Fernandes, Molecules 20 (2015) 16852-16891.

[22] L.S. Tsutsumi, D. Gündisch, D. Sun, Carbazole scaffold in medicinal chemistry and natural products: a review from 2010-2015, Curr. Top. Med. Chem. 16 (2016) 1290-1313.

[23] K.N. Mounika, A.N. Jyothy, G.N. Raju, R.R. Nadendla, World J. Pharm. Pharm. Sci. 4 (2015) $420-428$.

[24] M. Bashir, A. Bano, A.S. Ijaz, B.A. Chaudhary, Molecules 20 (2015) 13496-13517.

[25] C. Asche, M. Demeunynck, Anti Cancer Agents Med. Chem. 7 (2007) 247-267.

[26] A. Caruso, D. Iacopetta, F. Puoci, A.R. Cappello, C. Saturnino, M.S. Sinicropi, Mini-Rev. Med. Chem. 16 (2016) 630-643.

[27] T. Paneer, G. Saravanan, M. Palanivelu, Anticancer Evaluation of Thiazole Based Heterocycles - A Review, Lambert Academic Publishing, Saarbrücken, Germany, 2014. 
[28] A. Ayati, S. Emami, A. Asadipour, A. Shafiee, A. Foroumadi, Eur. J. Med. Chem. 97 (2015) $699-718$.

742

[29] A. Chawla, H. Kaur, P. Chawla, U.S. Baghel, J. Glob. Trends Pharm. Sci. 5 (2014) 1641-1648.

743

[30] A. Leoni, A. Locatelli, R. Morigi, M. Rambaldi, Expert Opin. Ther. Pat. 24 (2014) 201-216.

744 [31] K.K. Jha, S. Kumar, I. Tomer, R. Mishra, J. Pharm. Res. 5 (2012) 560-566.

745

[32] M.M. Ghorab, M.S. Bashandy, M.S. Alsaid, Acta Pharma. 64 (2014) 419-431.

746

[33] D. Gramec, L.P. Mašič, M.S. Dolenc, Chem. Res. Toxicol. 27 (2014) 1344-1358.

747

[34] N.C. Garbett, D.E. Graves, Curr. Med. Chem. Anticancer Agents 4 (2004) 149-172.

748

[35] C.M. Miller, F.O. McCarthy, RSC Adv. 2 (2012) 8883-8918.

749

[36] R.K. Mehmood, Oncol. Rev. 8 (2014) 256.

750

751

752

[38] S. Amptoulach, N. Tsavaris, Chemother. Res. Pract. (2011) 843019, , http://dx.

753

754

[39] M.A. Jordan, Curr. Med. Chem. Anticancer Agents 2 (2002) 1-17.

755 doi.org/10.1155/2011/843019.

759

[43] M. Reig, G. Bagdziunas, D. Volyniuk, J.V. Grazulevicius, D. Velasco, Phys. Chem. Chem. Phys. 19 (2017) 6721-6730.

761

762

763

[45] M. Reig, G. Bubniene, W. Cambarau, V. Jankauskas, V. Getautis, E. Palomares, E. MartínezFerrero, D. Velasco, RSC Adv. 6 (2016) 9247-9253. 
[46] M. Reig, J. Puigdollers, D. Velasco, J. Mater. Chem. C 3 (2015) 506-513.

[47] J.L. Díaz, A. Dobarro, B. Villacampa, D. Velasco, Chem. Mater. 13 (2001) 2528-2536.

[48] B.-B. Ma, Y.-X. Peng, T. Tao, W. Huang, Dalton Trans. 43 (2014) 16601-16604.

[49] Y.-X. Li, X.-T. Tao, F.-J. Wang, T. He, M.-H. Jiang, Org. Electron. 10 (2009) 910-917.

[50] S.-I. Kato, S. Shimizu, A. Kobayashi, T. Yoshihara, S. Tobita, Y. Nakamura, J. Org. Chem. 79 (2014) 618-629.

[51] S.-I. Kato, S. Shimizu, H. Taguchi, A. Kobayashi, S. Tobita, Y. Nakamura, J. Org. Chem. 77 (2012) 3222-3232.

[52] P. Wang, Y. Ju, S.Y. Tang, J.Y. Wu, H.P. Zhou, Acta Cryst., Sect. E 63 (2007) o3671.

[53] M.A.T. Nguyen, A.K. Mungara, J.-A. Kim, K.D. Lee, S. Park, Phosphorus Sulfur Silicon Relat. Elem. 190 (2015) 191-199.

[54] M.S. Shaikh, M.B. Palkar, H.M. Patel, R.A. Rane, W.S. Alwan, M.M. Shaikh, I.M. Shaikh, G.A. Hampannavar, R. Karpoormath, RSC Adv. 4 (2014) 62308-62320.

[55] M.H. Adbel-Kader (Ed.), Photodynamic Therapy from Theory to Applications, Springer, Heildelberg, Germany, 2014.

[56] J.U. Chukwu, C. López, A. González, M. Font-Bardía, M.T. Calvet, R. Messeguer, C. Calvis, J. Organomet. Chem. 766 (2014) 13-21.

[57] E. Guillén, A. González, C. López, P.K. Basu, A. Ghosh, M. Font-Bardía, C. Calvis, R. Messeguer, Eur. J. Inorg. Chem. (2015) 3781-3790.

[58] A. González, J. Granell, C. López, R. Bosque, L. Rodríguez, M. Font-Bardía, T. Calvet, X. Solans, J. Organomet. Chem. 726 (2013) 21-31.

[59] M. Tomé, C. López, A. Gonzalez, B. Ozay, J. Quirante, M. Font-Bardía, T. Calvet, C. Calvis, R. Messeguer, L. Baldomà, J. Badia, J. Mol. Struct. 1048 (2013) 88-97.

[60] C. López, A. González, R. Bosque, P.K. Basu, M. Font-Bardía, T. Calvet, RSC Adv. 2 (2012) 1986-2002.

[61] Z. Szafran, R.M. Pike, M.M. Singh, Microscale Inorganic Chemistry, A Comprehensive Laboratory Experience, John Wiley \& Sons, New York, USA, 1991, p. 218. 
[62] J.H. Price, A.N. Williamson, R.F. Schramm, B.B. Wayland, Inorg. Chem. 11 (1972) 12801284.

[63] S.H. Tucker, J. Chem. Soc. 129 (1926) 546-553.

[64] D.D. Perrin, W.L.F. Armarego, Purification of Laboratory Chemicals, fourth ed., ButterworthHeinemann, Oxford, UK, 1996.

[65] G.M. Sheldrick, Acta Cryst A64 (2008) 112-122.

[66] T.A. Halgren, J. Comput. Chem. 17 (1996) 490-519.

[67] Spartan '14 v. 1.1.0, Wavefunction, Inc, Irvine, CA, USA, 2013.

[68] P. Hohenberg, W. Kohn, Phys. Rev. 136 (1964) B864-B871.

[69] A.D. Becke, J. Chem. Phys. 98 (1993) 5648-5652.

[70] C. Lee, W. Yang, R.G. Parr, Phys. Rev. B 37 (1988) 785-789.

[71] M.J. Frisch, G.W. Trucks, H.B. Schlegel, G.E. Scuseria, M.A. Robb, J.R. Cheeseman, J.A. Montgomery, T. Vreven, K.N. Kudin, J.C. Burant, J.M. Millam, S.S. Iyengar, J. Tomasi, V. Barone, B. Mennucci, M. Cossi, G. Scalmani, N. Rega, G.A. Petersson, H. Nakatsuji, M. Hada, M. Ehara, K. Toyota, R. Fukuda, J. Hasegawa, M. Ishida, T. Nakajima, Y. Honda, O. Kitao, H. Nakai, M. Klene, X. Li, J.E. Knox, H.P. Hratchian, J.B. Cross, V. Bakken, C. Adamo, J. Jaramillo, R. Gomperts, R.E. Stratmann, O. Yazyev, A.J. Austin, R. Cammi, C. Pomelli, J.W. Ochterski, P.Y. Ayala, K. Morokuma, G.A. Voth, P. Salvador, J.J. Dannenberg, V.G. Zakrzewski, S. Dapprich, A.D. Daniels, M.C. Strain, O. Farkas, D.K. Malick, A.D. Rabuck, K. Raghavachari, J.B. Foresman, J.V. Ortiz, Q. Cui, A.G. Baboul, S. Clifford, J. Cioslowski, B.B. Stefanov, G. Liu, A. Liashenko, P. Piskorz,I. Komaromi, R.L. Martin, D.J. Fox, T. Keith, M.A. Al-Laham, C.Y. Peng, A. Nanayakkara, M. Challacombe, P.M.W. Gill, B. Johnson, W. Chen, M.W. Wong, C. Gonzalez, J.A. Pople, Gaussian 03 (Revision C.02), Gaussian, Inc, Wallingford, CT, 2004.

[72] P.C. Hariharan, J.A. Pople, Theor. Chim. Acta 28 (1973) 213-222.

[73] M.M. Francl, W.J. Pietro, W.J. Hehre, J.S. Binkley, M.S. Gordon, D.J. DeFrees, J.A. Pople, J. Chem. Phys. 77 (1982) 3654-3665.

[74] K.T. Givens, S. Kitada, A.K. Chen, J. Rothschiller, D.A. Lee, Invest. Ophthalmol. Vis. Sci. 31 (1990) 1856-1862. 
[75] A. Abdullah, F. Huq, A. Chowdhury, H. Tayyem, P. Beale, K. Fisher, BMC Chem. Biol. 6 (2006) 3.

[76] D.S. Sappal, A.K. McClendon, J.A. Fleming, V. Thoroddsen, K. Connolly, C. Reimer, R.K. Blackman, C.E. Bulawa, N. Osheroff, P. Charlton, L.A. Rudolph-Owen, Mol. Cancer Ther. 3 (2004) 47-58.

[77] A. Casini, C. Gabbiani, F. Sorrentino, M.P. Rigobello, A. Bindoli, T.J. Geldbach, A. Marrone, N. Re, C.G. Hartinger, P.J. Dyson, L. Messori, J. Med. Chem. 51 (2008) 6773-6781.

[78] M.E. Monge, S.M. Bonesi, R. Erra-Balsells, J. Heterocycl. Chem. 39 (2002) 933-941.

[79] J.Y. Lee, K.W. Song, H.J. Song, D.K. Moon, Synth. Met. 161 (2011) 2434-2440.

[80] T. Wang, Z. Zhang, N.A. Meanwell, J.F. Kadow, Z. Yin, Q.M. Xue, A. Regueiro-Ren, J.D. Matiskella, Y. Ueda, US. Pat. Appl. Publ. (2004) US 20040110785.

[81] D. Kim, J.K. Lee, S.O. Kang, J. Ko, Tetrahedron 63 (2007) 1913-1922.

[82] R. Parthasarathy, B. Paul, W. Korytnyk, J. Am. Chem. Soc. 98 (1976) 6634-6643.

[83] T. Murai, F. Hori, T. Maruyama, Org. Lett. 13 (2011) 1718-1721.

[84] Z.-C. Song, G.-Y. Ma, H.-L. Zhu, RSC Adv. 5 (2015) 24824-24833.

[85] A.R. Stefankiewicz, A. de Cian, J. Harrowfield, CrystEngComm 13 (2011) 7207-7211.

[86] Z.-C. Song, G.-Y. Ma, P.-C. Lv, H.-Q. Li, Z.-P. Xiao, H.-L. Zhu, Eur. J. Med. Chem. 44 (2009) 3903-3908.

[87] A. Bondi, J. Phys. Chem. 68 (1964) 441-451.

[88] G.R. Desiraju, T. Steiner, The weak hydrogen bond in structural chemistry and biology, IUCR Monographs on Crystallography, vol. 9, Oxford University Press, Oxford, UK, 1999.

[89] J. Gu, W.-Q. Chen, T. Wada, D. Hashizume, X.-M. Duan, CrystEngComm 9 (2007) 541-544.

[90] P. Xue, B. Yao, J. Sun, Z. Zhang, R. Lu, Chem. Commun. 50 (2014) 10284-10286.

[91] N.A. Kazin, Y.A. Kvashnin, R.A. Irgashev, W. Dehaen, G.L. Rusinov, V.N. Charushin, Tetrahedron Lett. 56 (2015) 1865-1869.

[92] J.B. Seneclauze, P. Retailleau, R. Ziessel, New J. Chem. 31 (2007) 1412-1416. 
849

850

851

852

853

854

855

856

857

858

859

860

861

862

863

864

865

866

867

868

869

870

871

872

873

[93] Cambridge Crystallographic Data Centre, Available online: www.ccdc.cam.ac.uk/data_request/cif.

[94] Y.-W. Li, G.-B. Gu, H.-Y. Liu, H.H.Y. Sung, I.D. Williams, C.-K. Chang, Molecules 10 (2005) 912-921.

[95] F. Accadbled, B. Tinant, E. Henon, D. Carrez, A. Croisy, S. Bouquillon, Dalton Trans. 39 (2010) 8982-8993.

[96] C. López, A. Caubet, S. Pérez, X. Solans, M. Font-Bardía, Chem. Commun. (2004) 540-541.

[97] C. López, A. Caubet, S. Pérez, X. Solans, M. Font-Bardía, E. Molins, Eur. J. Inorg. Chem. (2006) 3974-3984.

[98] D. Talancón, C. López, M. Font-Bardía, T. Calvet, J. Quirante, C. Calvis, R. Messeguer, R. Cortés, M. Cascante, L. Baldomà, J. Badía, J. Inorg. Biochem. 118 (2013) 1-12.

[99] M. Crespo, M. Font-Bardía, J. Granell, M. Martínez, X. Solans, Dalton Trans. (2003) 37633769.

[100] M. Crespo, R. Martín, T. Calvet, M. Font-Bardía, X. Solans, Polyhedron 27 (2008) 2603-2611.

[101] C. López, R. Bosque, M. Pujol, J. Simó, E. Sevilla, M. Font-Bardía, R. Messeguer, C. Calvis, Inorganics 2 (2014) 620-648.

[102] C. López, C. Moya, P.K. Basu, A. González, X. Solans, M. Font-Bardía, T. Calvet, E. Lalinde, M.T. Moreno, J. Mol. Struct. 999 (2011) 49-59.

[103] F.H. Allen, Acta Crystallogr. Sect. B: Struct. Sci. B58 (2002) 380-388.

[104] G.A. Crosby, J.N. Demas, J. Phys. Chem. 75 (1971) 991-1024.

[105] S. Chattoraj, A. Amin, B. Jana, S. Mohapatra, S. Ghosh, K. Bhattacharyya, ChemPhysChem 17 (2016) 253-259.

[106] M. Zahedifard, F.L. Faraj, M. Paydar, C.Y. Looi, M. Hajrezaei, M. Hasanpourghadi, B. Kamalidehghan, N.A. Majid, H.M. Ali, M.A. Abdulla, Sci. Rep. 5 (2015) 11544.

[107] P.D. Leeson, B. Springthorpe, Nat. Rev. Drug Discov. 6 (2007) 881-890.

[108] C.H. Reynolds, B.A. Tounge, S.D. Bembenek, J. Med. Chem. 51 (2008) 2432-2438.

[109] J.A. Arnott, R. Kumar, S.L. Planey, J. Appl. Biopharm. Pharmacokinet. 1 (2013) 31-36. 
874 [110] K.D. Freeman-Cook, R.L. Hoffman, T.W. Johnson, Future Med. Chem. 5 (2013) 113-115.

875 [111] W. Wang, X. Sun, D. Sun, S. Li, Y. Yu, T. Yang, J. Yao, Z. Chen, L. Duan, ChemMedChem 11 $876 \quad$ (2016) 2675-2681.

877 [112] For a general overview of the role of Topoisomerases in cancer see for instance: $\mathrm{Y}$. Xu, C. Her, 878 Biomolecules 5 (2015) 1652-1670.

879 [113] S.P. Fricker, Metallomics 2 (2010) 366-377.

880 
883 Figure. 1. Carbazole and two naturally occurring carbazole derivatives (Ellipticine and Glybomine-B and $\mathrm{C}$ ) with potent cytotoxic activities in front of several cancer cell lines.

885

Scheme 1 Synthesis of carbazoles 1a and 1b. Reagents and conditions: i) KI, KIO3, acetic acid, reflux.

ii) $\mathrm{NaH}, \mathrm{DMF}$, room temperature followed by treatment with iodomethane, in DMF at room temperature. iii) 2-(Tributylstannyl) thiazole, [Pd(PPh3)4], DMF, $100{ }^{\circ} \mathrm{C}$. iv) 2-

(Tributylstannyl)thiophene, [Pd (PPh3)4], DMF, $100{ }^{\circ} \mathrm{C}$.

890

891

Figure. 2. Atom labelling scheme for ligands $1 \mathrm{a}$ and $1 \mathrm{~b}$.

892

893

Figure. 3.Molecular structure and atom labelling scheme for the new hybrid carbazole-thiazole ligand (1a).

Figure. 4 Schematic view of: A) the assembly of a molecule of 1a, sited at (x, y, z) and another unit at $(-1+x, y, z)$ by $\pi-\pi$ stacking between the thiazolyl and the phenyl ring of the carbazole (in purple) and $\mathrm{CeH} \cdots \pi$ short contacts (green dotted lines) involving one of the methyl protons (H10) and the propagation of these interactions along the crystal to give pillars; B) simplified view of connectivity of

Scheme 2 Synthesis of the complexes. Reagents and conditions: i) trans-[PdCl2(dmso)2] in refluxing methanol $(1 \mathrm{~h})$ or Na2[PdCl4] in methanol at $298 \mathrm{~K}, 24 \mathrm{~h}$ [molar ratios Pd(II):1a=1:1 and 1:2, respectively]; ii) cis-[PtCl2(dmso)2] in refluxing methanol $(1 \mathrm{~h})$ and iii) equimolar amounts of cis[PtCl2(dmso)2] and $\mathrm{NaOAc}$ in a toluene: $\mathrm{MeOH}$ (5:1) mixture under reflux \{see text and Table 2,

Figure. 5..Highest occupied molecular orbital (HOMO) and lowest unoccupied molecular orbital (LUMO) for the new carbazole derivatives (1a and 1b).

Figure. 6..Plot of the energy of the molecule of $1 \mathrm{a}$ (blue) or $1 \mathrm{~b}$ (red) versus the value of the torsion angle S1-C2'-C3-C4 $(\varphi)$. (For interpretation of the references to colour in this figure legend, the reader is referred to the web version of this article.) 
915 Figure. 7. Comparative plot of the IC50 values (in $\mu \mathrm{M}$ ) of the new carbazoles (1a and $1 \mathrm{~b}$ ), the $\mathrm{Pd}$ (II) and $\mathrm{Pt}$ (II) complexes derived from 1a and cisplatin in front of the colon cancer cell line (HCT116) and the two breast cancer cell lines (MDA-MB231 and MCF7).

919 Figure. 8. Interaction of pBluescript SK + plasmid DNA $(40 \mu \mathrm{g} / \mathrm{mL})$ with increasing concentrations of compounds 1a, 1b, 2a and 3a, ethidium bromide (EB) and cisplatin. Lane 1: DNA only; Lane 2: $1 \mu \mathrm{M}$; Lane 3: $2.5 \mu \mathrm{M}$; Lane 4: $5 \mu \mathrm{M}$; Lane 5: $10 \mu \mathrm{M}$; Lane 6: $25 \mu \mathrm{M}$; Lane 7: $50 \mu \mathrm{M}$; Lane 8: $100 \mu \mathrm{M}$; Lane 9: $200 \mu \mathrm{M}$. Ccc represents the supercoiled closed circular form and oc the open circular form.

Figure 9. Analysis of the new ligands (1a and $1 \mathrm{~b}$ ) and compounds $2 \mathrm{a}$ and $3 \mathrm{a}$ as potential DNA intercalators or Topoisomerase I inhibitors. Conversion of supercoiled pBluescript SK+ DNA (40 $\mu \mathrm{g} / \mathrm{mL}$ ) to relaxed DNA by the action of Topoisomerase I ( 3 units) in the absence or in the presence of increasing amounts of compounds. $\mathrm{E}=100 \mu \mathrm{M}$ etoposide; $\mathrm{EB}=10 \mu \mathrm{M}$ Ethidium Bromide;

$928 \mathrm{SC}=$ supercoiled DNA as control; $\mathrm{R}=$ relaxed DNA by the action of Topoisomerase I as control; Lane 1: $100 \mu \mathrm{M}$; Lane 2: $200 \mu \mathrm{M}$; $\mathrm{ccc}=$ closed circular form and $\mathrm{oc}=$ open circular form.

Figure. 10. A) Topoisomerase-II $\alpha$ inhibitory activity of compounds 1a, 1b, 2a and 3a. Reactions contained supercoiled plasmid DNA, Topoisomerase II $\alpha$ (4 units) and $100 \mu \mathrm{M}$ of the indicated compound. B) Topoisomerase II $\alpha$ inhibitory activity of compound 2a at different concentrations: Lane 1: $50 \mu \mathrm{M}$; Lane 2: $100 \mu \mathrm{M}$ and Lane 3: $200 \mu \mathrm{M}$. In all experiments, control reactions were performed in the presence of: E: etoposide at $100 \mu \mathrm{M}$; P: SC Plasmid DNA only; T: reaction performed with plasmid DNA and Topoisomerase II $\alpha$ (4 units). 
940

941<smiles>c1ccc2c(c1)[nH]c1ccccc12</smiles>

Carbarole<smiles>Cc1c2ccncc2c(C)c2c1[nH]c1ccccc12</smiles>

Fmincing

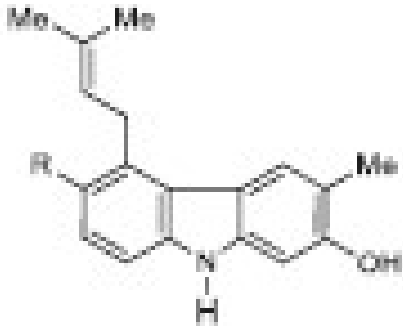

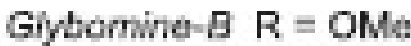
Glyomino-C $\mathrm{R}=\mathrm{OH}$ 
945

946

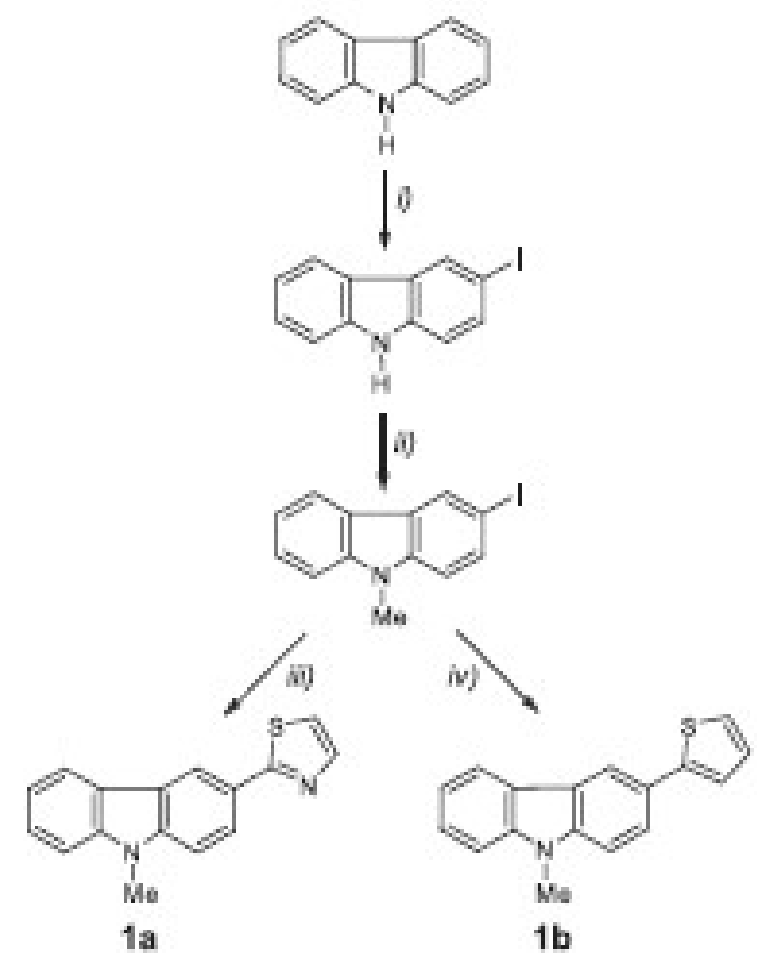


950

951

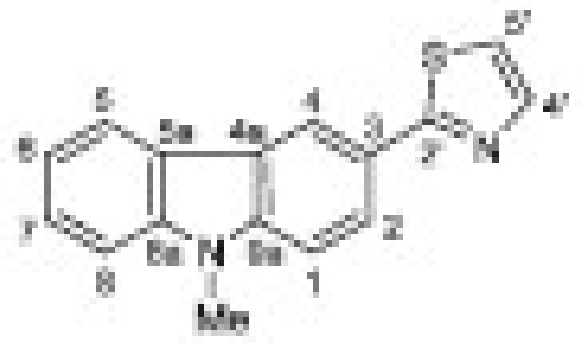

$1 \mathrm{~g}$

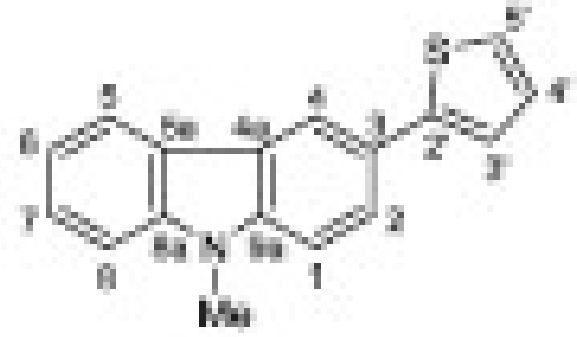

1b

952

953 


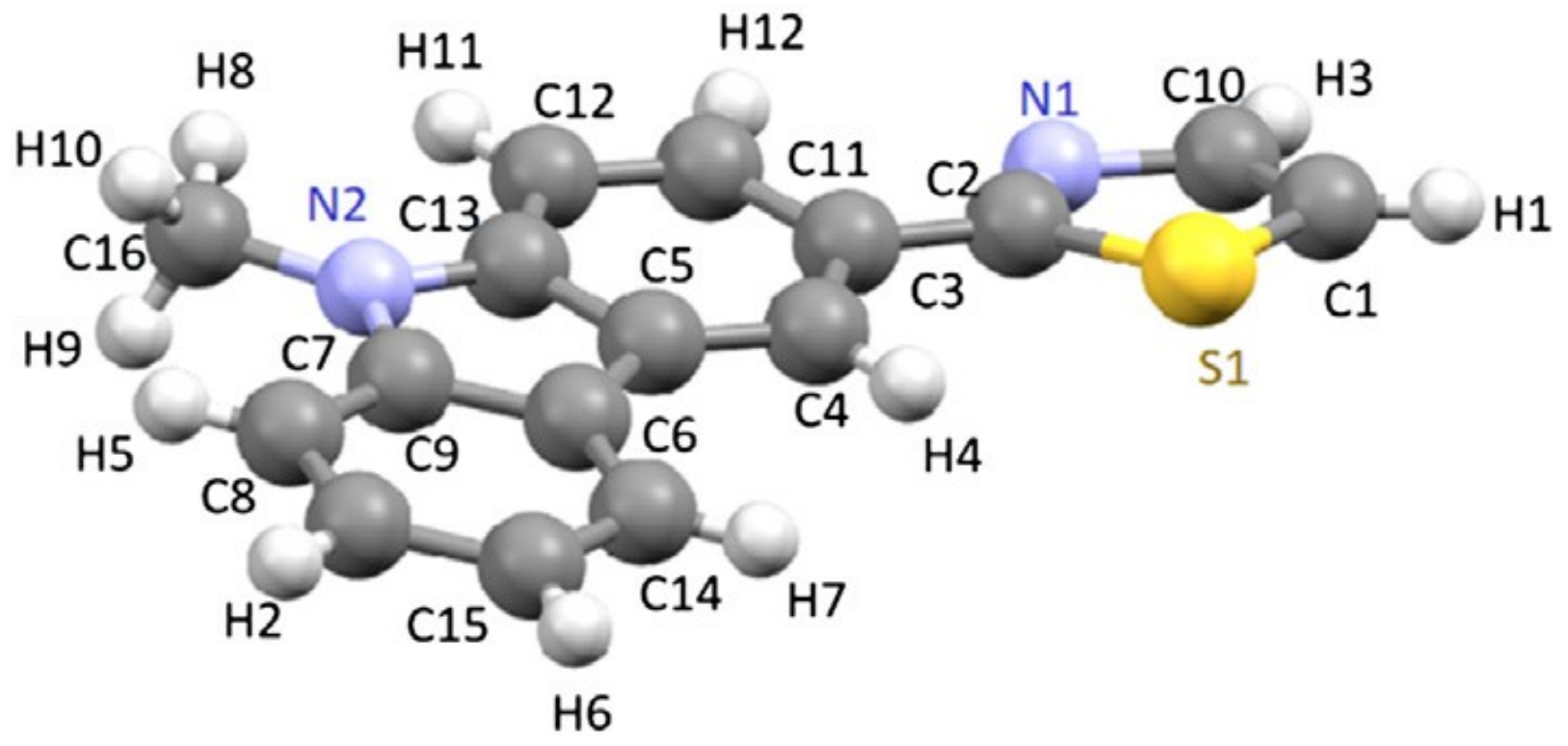


960

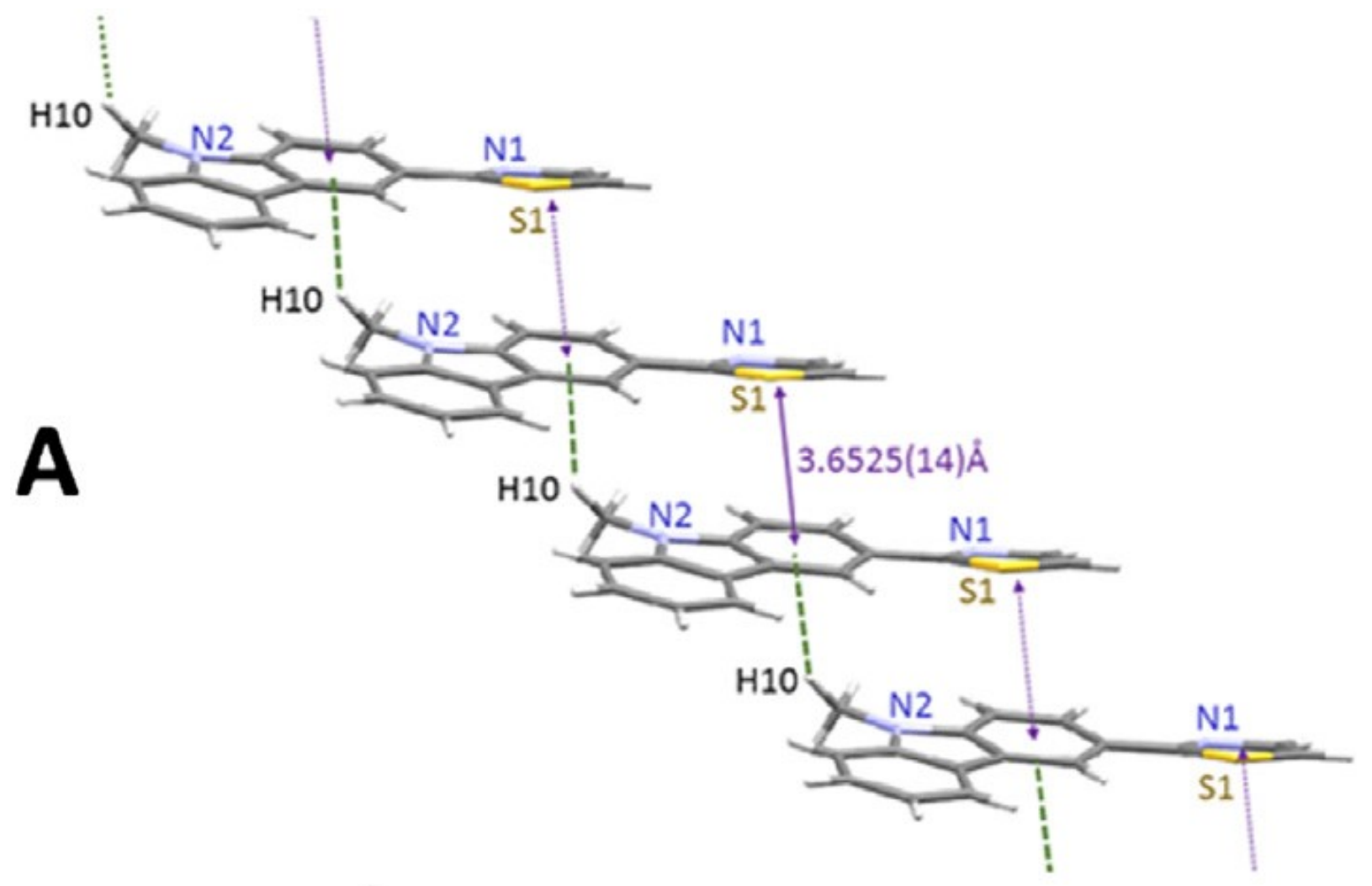

B

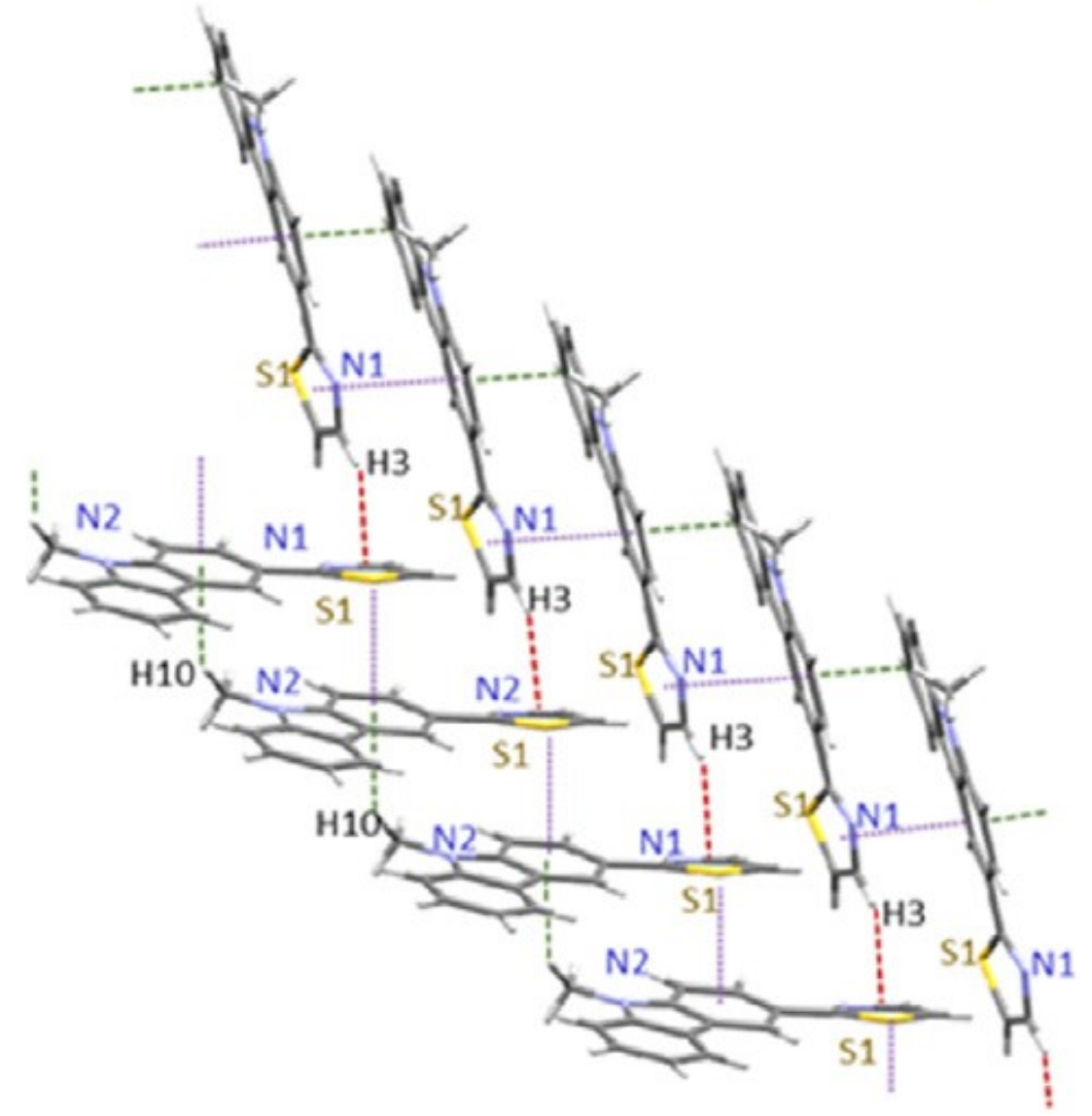




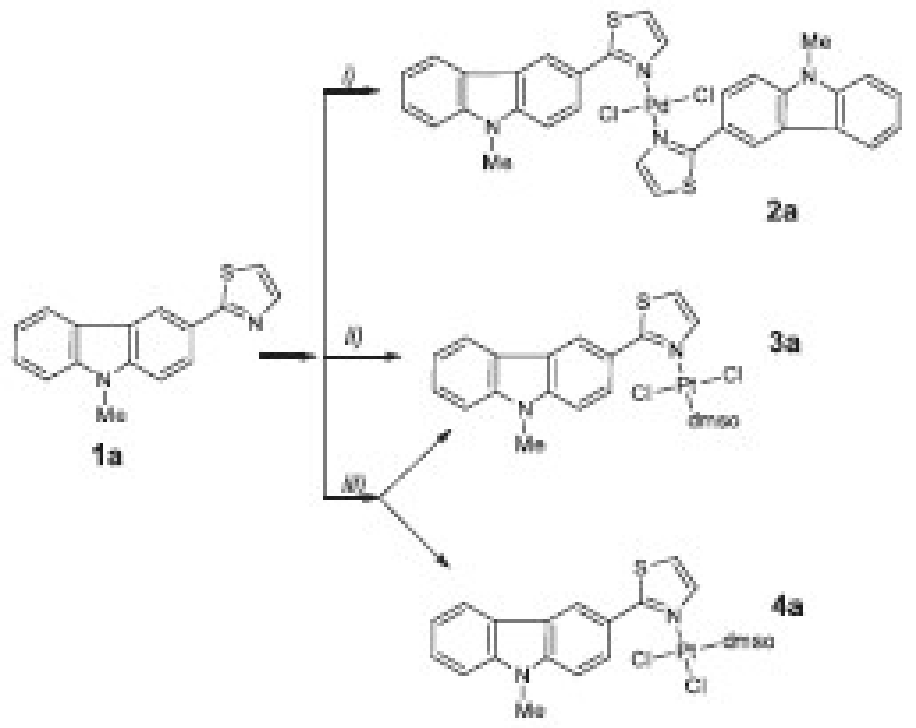

967 
970
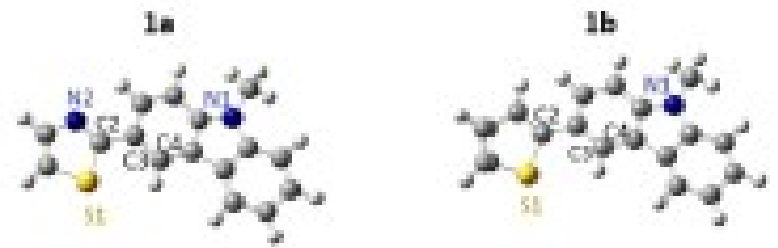

971
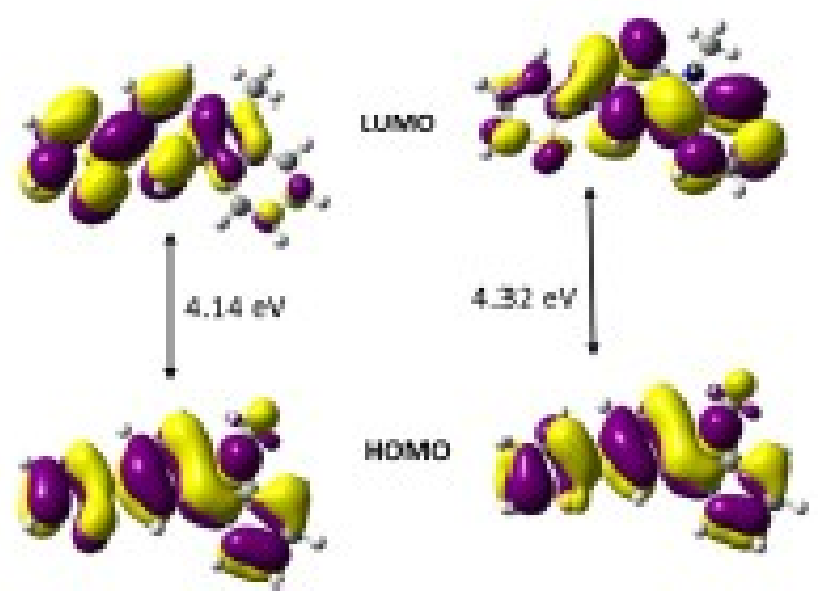

972 


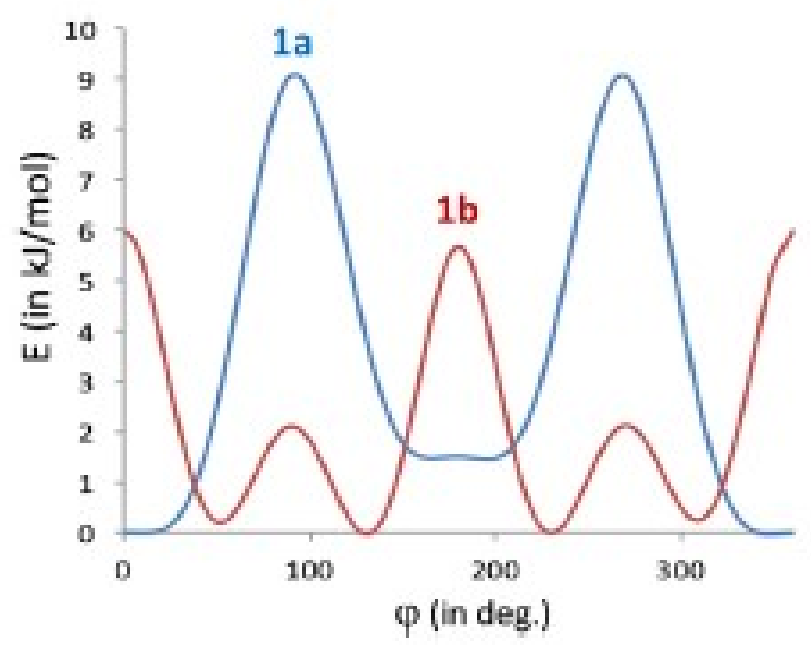

977 


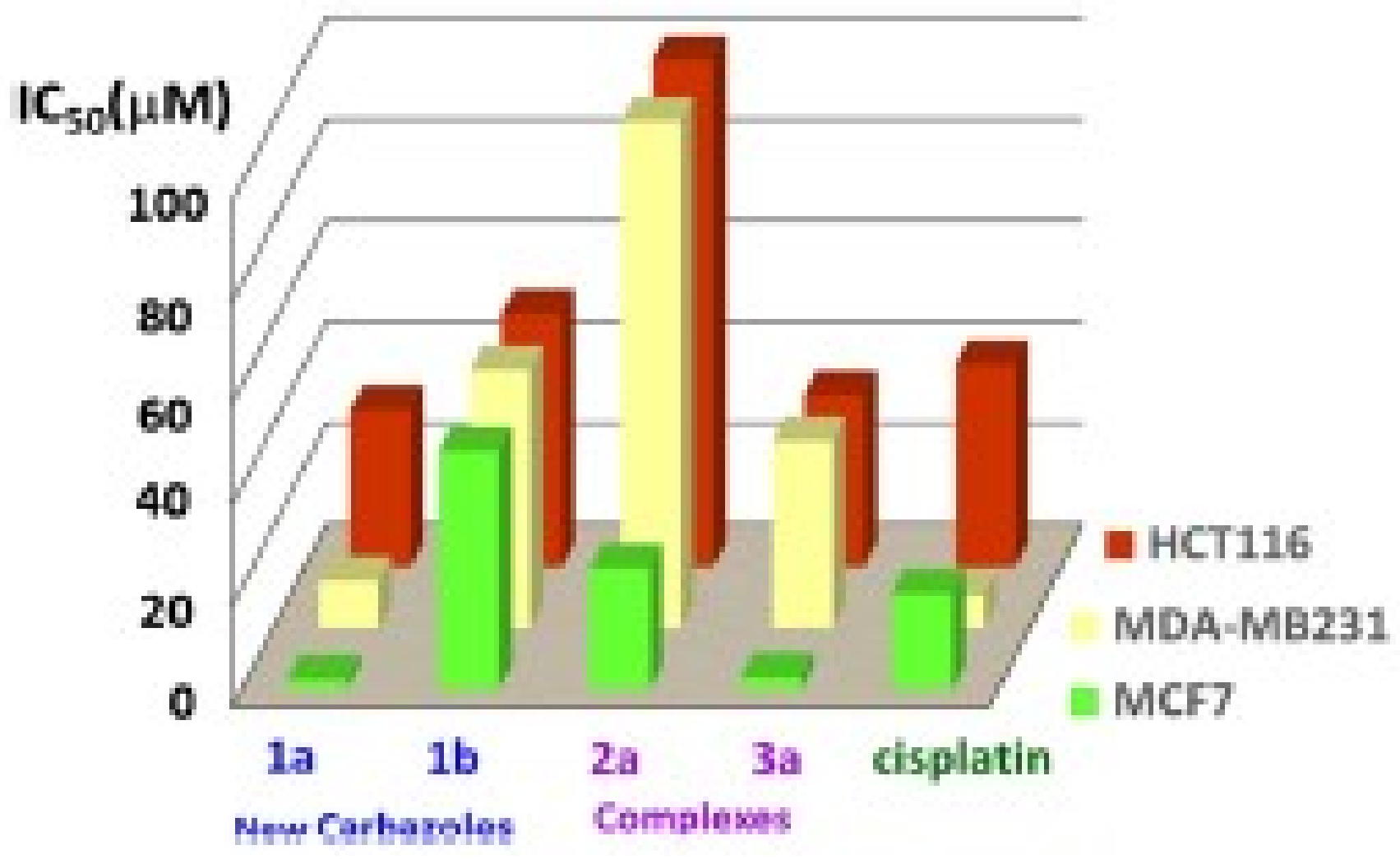


FIGURE 8

982

983

984

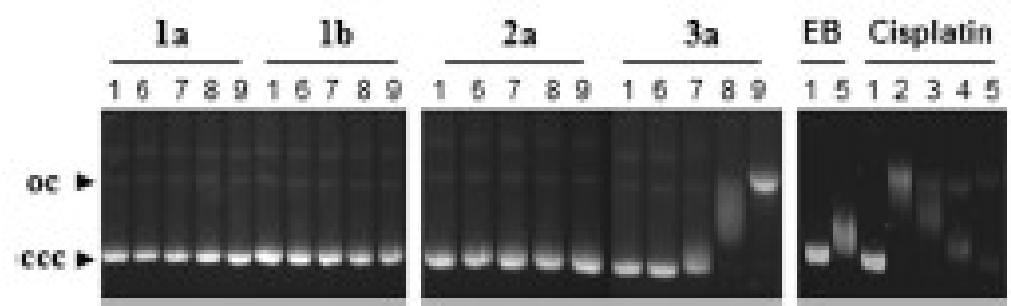

985 
FIGURE 9

987

988

989

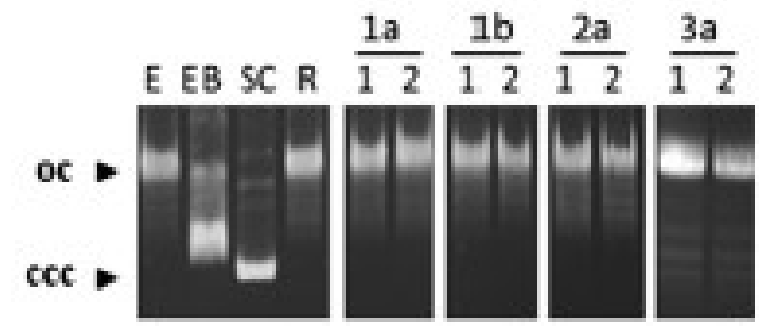

990 
FIGURE 10

992

993

A)

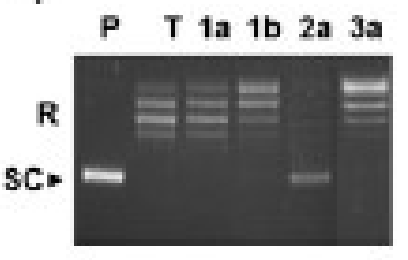

B) $E P T \frac{2 a}{1 \quad 2 \quad 3}$

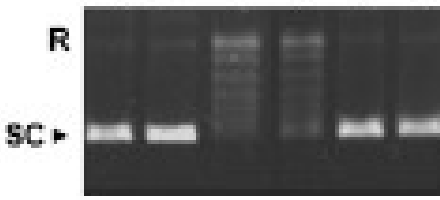


995 Table 1.. Crystal data and details of the refinement for compound 1a.

996

\begin{tabular}{|c|c|}
\hline Fimpifed sormala & $\mathrm{C}_{46} \mathrm{H}_{1} 2 \mathrm{~N}_{5} \mathrm{~S}$ \\
\hline Formula meiglat & 26434 \\
\hline Tempeature/K & $100[2]$ \\
\hline $2 / \lambda^{2}$ & a.7073 \\
\hline 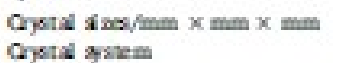 & $\begin{array}{l}\text { 0.2:2 } \times 0.168 \times 0.048 \\
\text { Ordbothanbie }\end{array}$ \\
\hline Space group & $P 2_{1} 2_{1} 2_{4}$ \\
\hline$\Phi / \mathcal{A}$ & $6.0702(2)$ \\
\hline$\Delta / A$ & $128577(5)$ \\
\hline$</ A$ & $160721(6)$ \\
\hline$a-\beta-\gamma / \operatorname{deg}$ & 90 \\
\hline$v / R^{n}$ & $1234.41(8)$ \\
\hline $\mathbf{z}$ & 4 \\
\hline Denality (ealeulanal) $/ \mathrm{Mg}_{8} \times \mathrm{m}^{-3}$ & 1.400 \\
\hline$H^{\prime} \min ^{-1}$ & 0.243 \\
\hline$P(000)$ & 552 \\
\hline A rasge for duea collax boan/seg. & from 2028 × 27.498 \\
\hline labex nages & $-7 \leq A \leq 7,-16 \leq k \leq 16,-20 \leq l \leq 20$ \\
\hline Completeness to $\Theta-25.24 Z$ & 92.85 \\
\hline Aboorpiode eorrestiod & Semiempiscd from apuivileas \\
\hline Mor. and min trassmbaion & 0.7456 and 0.6711 \\
\hline Refinement medbod & Rullexax leax-squeses on $F^{2}$ \\
\hline Dav/reariants/puramenes & $28 \overline{5} / 0 / 173$ \\
\hline Goodiness-of-fit on $F^{2}$ & 1.074 \\
\hline Find Rincies $[I>20(\mathrm{~T})]$ & $R_{4}=0.0358, w R_{2}=0.0743$ \\
\hline R indices (all dav) & $R_{1}=0.0471, m R_{2}=0.0901$ \\
\hline Noboluse structure pasameter & $0.04(4)$ \\
\hline largest diff. peik and hole/e $\mathcal{h}^{-3}$ & 0.241 asd -0.234 \\
\hline
\end{tabular}


999 Table 2 Summary of experimental conditions [reagents, molar ratios (1a:Pd(II) or 1a:Pt(II)), solvents, 1000 temperature $(\mathrm{T})$, reaction time ( $\mathrm{t}$, in $\mathrm{h})$ ] used in the study of the reactivity of carbazole 1a with trans1001 [PdCl2(dmso)2], Na2[PdCl4] or cis-[PtCl2(dmso)2].

1002

\begin{tabular}{|c|c|c|c|c|c|c|}
\hline Fandy & Reagents & Molar raciod & Saver & $\mathbf{T}$ & $t$ & Find poodoets \\
\hline I & 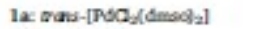 & $(1: 1)$ of (2:1) & $\mathrm{MOH}$ & Beflax & 1 & $2 a$ \\
\hline II & $1 \alpha=\mathrm{N}_{2}\left[\mathrm{PAC}_{4}\right]$ & (1:1) of (2:1) & $\mathrm{MeOH}$ & $298 \mathrm{~K}$ & 24 & $2 \mathrm{a}$ \\
\hline III & 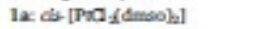 & (1:1) & $\mathrm{N \omega OH}$ & Reflax & 1 & 3a \\
\hline N & 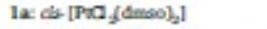 & (1:1) & $\mathrm{MeOH}$ & Reflax & 24 & 3a \\
\hline$v$ & 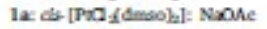 & (1:1:1) & Tolume/NeOH" & Penax & 24 & 3a and $4 a^{\circ}$ \\
\hline n & 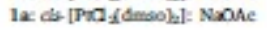 & (1:1:1) & Tolvene/NeOH" & Reflax & 72 & 3a and $4 a^{2}$ \\
\hline
\end{tabular}

1003

Only traces of compound 4 ware detectsd.

${ }^{e}$ Integration of the signals observed in the ${ }^{1}$ HNMR spectrum of the raw material indicatsd that the molar ratio 3aj4a was 1.7. 
1005 Table 3 Absorption and emission properties of the free carbazoles (1a and $1 \mathrm{~b}$ ) and the $\operatorname{Pd}(\mathrm{II})$ and $\operatorname{Pt}(\mathrm{II})$ 1006 complexes (2a and 3a, respectively) in $\mathrm{CH} 2 \mathrm{Cl} 2$ [Wavelengths $\lambda \mathrm{i}$ (in nm), logarithms of the extinction 1007 coefficients ( $\log \varepsilon i)$, emission wavelengths $[\lambda \mathrm{em}$ (in $\mathrm{nm}$ ) after excitation at $\lambda \mathrm{exc}=300 \mathrm{~nm}$ ] and quantum 1008 yields $(\Phi)$.

1009

1010

\begin{tabular}{|c|c|c|c|}
\hline \multirow[t]{2}{*}{ Compd. } & \multirow{2}{*}{ 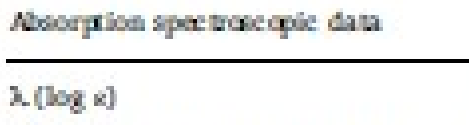 } & \multicolumn{2}{|c|}{ Fmbesiod spex orecepie dava } \\
\hline & & $x_{\max }$ & 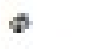 \\
\hline la & $3 \times 8(4.3), 301(4.5), 279$ sh $(-4.2)$ & 370 sh, 384 & 0.22 \\
\hline $1 b$ & $317(-4.2), 299(4.5)$ & 376,394 & 0.12 \\
\hline $2 a$ & $334(3.6), 300(3.8), 284(-3.8)$ & 370 sh, 395 & 0.02 \\
\hline $3 a$ & $345(4.2), 301(4.4), 287(4.4)$ & 370 sh, 39 & $<0.01$ \\
\hline
\end{tabular}

1011

1012

1013

1014 
1015 Table 4 Cytotoxic activities (IC50 valuesa, $\mu \mathrm{M}$ ) on the cancer cell lines: HCT116 (colon), MDA-

1016 MB231 and MCF7 (breast) and the normal non-tumoral human skin fibroblast BJ cells, for 1a, 1b and

1017 the palladium(II) and platinum(II) complexes derived from 1a (2a and 3a, respectively) and for cisplatin.

1018 For comparison purposes, Clog P valuesb and lipophilic efficiencies (LipEc) of compounds 1a, 1b, 2a

1019 and 3a on the MCF7 cell line are also included

1020

\begin{tabular}{|c|c|c|c|c|c|c|}
\hline \multirow[t]{2}{*}{ Compounds } & \multicolumn{4}{|c|}{$\mathrm{X}_{\text {sa }}$ values in the cell lines" } & \multirow[t]{2}{*}{ Cloypt } & \multirow[t]{2}{*}{$I \varphi E^{\prime}$} \\
\hline & HCr 116 & MDA-MR231 & $\mathrm{MCF} 7$ & RJ & & \\
\hline \multicolumn{7}{|l|}{ Cuntionles } \\
\hline la & $31 \pm 2$ & $9.4 \pm 2.6$ & $20 \pm 0.5$ & $>100$ & 4.42 & 1.27 \\
\hline ib & $50 \pm 4$ & $51 \pm 3$ & $47 \pm 3$ & $>100$ & 5.73 & -1.39 \\
\hline \multicolumn{7}{|l|}{ Conpieres } \\
\hline $2 a$ & $>100$ & $>100$ & $24 \pm 2$ & $>100$ & 9.42 & -4.80 \\
\hline $3 a$ & $34 \pm 3.5$ & $37 \pm 3.6$ & $2.4 \pm 2.2$ & $>100$ & 4.33 & 1.29 \\
\hline Cyplatin & $40 \pm 4.4$ & $6.5 \pm 24$ & $19 \pm 4.5$ & $12 \pm 2$ & - & - \\
\hline
\end{tabular}

" Dats are shown as the mesn values of two experiments performed in tri. plicats.

b $C \log P$ is the calculated $\log a r i t h m i c$ value of the n-octanol/water partition coefficient and was calculated uring the Chemilo DrawUltra computer program.

'IfpF inderes were calaulated as $I$ pFE $=-\log \left(1 C_{\infty}\right)-C \log P[107-110]$ and using the $\mathrm{IC}_{\mathrm{g}}$ values obtained in the MCF7 cell line. 